RUNNING HEAD: Sex differences, cognitive reserve, and Alzheimer's

\title{
Sex differences in cognitive reserve: implications for Alzheimer's Disease in women
}

Sivaniya Subramaniapillai ${ }^{1,2^{*}}$, Anne Almey ${ }^{3 *}$, M. Natasha Rajah ${ }^{2,4}$, Gillian Einstein ${ }^{3,5,6}$

*The authors contributed equally to the writing of this manuscript.

1. Department of Psychology, McGill University, 2001 Avenue McGill College, Montréal, QC, Canada, H3A $1 \mathrm{G} 1$

2. Brain Imaging Centre, Douglas Institute Research Centre, 6875 LaSalle Blvd Verdun, Montréal, QC, Canada, $\mathrm{H} 4 \mathrm{H} 1 \mathrm{R} 3$

3. Department of Psychology, University of Toronto, 100 St. George Street, Toronto, ON, Canada, M5S $3 G 3$

4. Department of Psychiatry, Faculty of Medicine, McGill University, 1033 Avenue des Pins, Montréal, QC, Canada, H3A $1 \mathrm{~A} 1$

5. Rotman Research Institute, Baycrest Hospital, 3560 Bathurst St, Toronto, ON, Canada, M6A 2 E1

6. Tema Genus, Linköping University, TEMA-huset, Entrance 37, Room E433, Campus Valla, Linköping, Sweden

\section{Corresponding Author:}

Sivaniya Subramaniapillai

Brain Imaging Centre, Douglas Institute Research Centre

6875 LaSalle Blvd Verdun

Montréal, QC, Canada, H4H 1R3

sivaniya.subramaniapillai@mail.mcgill.ca 
RUNNING HEAD: Sex differences, cognitive reserve, and Alzheimer's

\begin{abstract}
Women represent $2 / 3$ of the cases of Alzheimer's disease (AD). Current research has focused on differential risks to explain higher rates of $A D$ in women. However, factors that reduce risk for $A D$, like cognitive reserve, are less well explored. We asked: what is known about sex differences in how cognitive reserve mitigates risk for $A D$ ? To address this, we conducted a narrative review of the literature. Keywords were: "sex/gender differences", "cognitive/brain reserve", "Alzheimer's Disease", and the following cognitive reserve contributors: "education”, “IQ", “occupation”, “cognitive stimulation”, "bilingualism”, "socioeconomic status", "physical activity", "social support". Fifteen papers disaggregated their data by sex. Those papers observed sex differences in cognitive reserve contributors. There is also evidence that a subset of women may have greater resistance to $A D$, possibly due to greater cognitive reserve. We discuss how traditional cognitive reserve contributors are gendered and may not capture factors that support cognition in aging women.
\end{abstract}

Keywords: cognitive reserve, brain reserve, sex, gender, Alzheimer's disease, resistance, resilience 


\section{RUNNING HEAD: Sex differences, cognitive reserve, and Alzheimer's}

\section{Introduction}

Currently, over 65\% of people with late-onset Alzheimer's Disease (AD) are women (Association, 2019; Bailly et al., 2019; Mielke et al., 2014; Nebel et al., 2018; Schmidt et al., 2008). In fact, after age, sex is one of the strongest risk factors for developing $A D$ (Table 1). It has also been hypothesized that the higher rate of $A D$ in women compared to men may be because women are more negatively affected by some of the known risk factors for AD, than men (Table 1). For example, having an apolipoprotein E e4 allele (+APOE4) places women at a higher risk of developing $A D$, compared to men). Indeed, women in their sixties carrying one or two APOE4 alleles have a greater risk of developing AD compared to their male counterparts (Bretsky et al., 1999b; Farrer et al., 1997). Importantly, female-specific hormonal transitions including puberty, parity and menopause can help in our understanding of why women are more likely to be diagnosed with AD (see Table 2). Earlier onset of menopause, either surgical (ovarian removal) or spontaneous (gradual cessation of menses at $\sim 51 y r s$ ), is associated with increased AD/dementia risk (Bove et al., 2014; Fox et al., 2013a; Gilsanz et al., 2019; Rocca et al., 2007). Total reproductive years (age at menarche to age at menopause) has repeatedly been shown to be negatively correlated with the rate of AD diagnosis, indicating that duration of ovarian hormone exposure protects against AD (Fox et al., 2013a; Gilsanz et al., 2019). In fact, there is evidence that the $17 \beta$-estradiol (E2) decline at menopause may contribute to cognitive decline in women at late midlife, and that estrogen replacement initiated shortly after menopause reduces the incidence of AD (Kawas et al., 1997; Merlo et al., 2017; Shao et al., 2012; Tang et al., 1996; Whitmer et al., 2011). While estrogen replacement following menopause has been shown to promote resistance (i.e., the ability to delay AD onset, discussed below), many women who do not take estrogen therapy do not get $A D$, so factors beyond ovarian hormones contribute to the sex difference in AD.

Although significant consideration has been placed on sex as a risk factor for AD, little is known about the role of gender ${ }^{1}$. Interestingly, although risk factors for AD overlap for women and men, there are sex

1 "Sex refers to the biological attributes that distinguish organisms as male, female, or intersex...gender refers to psychological, social and cultural factors that shape attitudes, behaviours, stereotypes, technologies and knowledge. Gender includes three related dimensions. Gender norms refer to spoken and unspoken rules in the family, workplace, institution or global culture that influence individuals. Gender identity refers to how individuals and groups perceive and present themselves within specific cultures. Gender relations refer to power relations between individuals with different gender roles and identities." (Tannenbaum et al., 2019). 


\section{RUNNING HEAD: Sex differences, cognitive reserve, and Alzheimer's}

differences in the effect of these risk factors. There are also general health moderators, such as mental health, sleep, and cardiovascular fitness (Table 3), which can interact with AD risk factors to increase susceptibility to $A D$ in both sexes. It is possible that these health moderators have sex-specific effects. For example, women are more commonly diagnosed with mood disorders, which include major depressive disorder, generalized anxiety disorder, social anxiety disorders, and post-traumatic stress disorder (Kessler, 2003; Kessler et al., 2005, 1993; Parker and Brotchie, 2010; Weissman and Klerman, 1977). Differences in how women and men perceive, respond, and react to stress may contribute to women's elevated response to stressors and increased stress-related pathology like depression and anxiety diagnoses (Bangasser and Valentino, 2014; Bangasser and Wicks, 2017; Bangasser and Wiersielis, 2018). It is not possible to quantify how these health moderators specifically interact with AD risk factors in women, compared to men, but one possibility is that higher rates of mood disorders and perceived stress may contribute to the elevated levels of AD in women (for review see Mielke et al., 2014; Nebel et al., 2018; Podcasy and Epperson, 2016). Since gender interacts with many of these health moderators and AD-specific risk factors, it may also play a role in the differential frequency of $A D$ in men and women.

It is critical to better understand what factors prevent or delay AD in women and men, since this would allow for sex-specific interventions that could stave off AD. The accumulation of reserve across the lifespan is one such factor (Stern, 2002). Reserve has been operationalized as the gradual accumulation of neural resources across the lifespan which can preserve cognitive function by reducing the effects of age- and ADrelated neuropathology (Barulli and Stern, 2013; Cabeza et al., 2018). Importantly, these neural resources can be reflected in terms of brain reserve and/or cognitive reserve.

Brain reserve is a quantitative measure of neural capacity (e.g., overall brain size, number of neurons/synapses) that supports cognitive performance (Barulli and Stern, 2013). Cognitive reserve is a more dynamic measure of reserve and can be reflected in terms of greater neural efficiency (i.e., lower activity required for equivalent performance) and/or higher compensation (i.e., recruitment of alternative regions or networks to support performance, not typically recruited for that task). Factors thought to contribute to reserve (sometimes called proxies but referred to here as contributors) are education level, occupational complexity, Intelligence Quotient (IQ), cognitively stimulating activities, bilingualism, socioeconomic status (SES), physical activity, and social support. Greater reserve capacity, resulting from an increased lifetime engagement in these contributors is hypothesized to protect against cognitive decline, accumulation of neuropathology, and onset of AD (Baldivia et al., 2008; Barulli and Stern, 2013; Calvo et al., 2016; Stern, 2012, 
2002). In the domain of AD research, it has been hypothesized that individuals with high reserve will show: 1) later cognitive declines in the face of AD pathology (Fig 1 point of inflection; called resistance); 2) later clinical diagnosis of $A D$ in the face of worse pathology; 3) worse AD pathology at any level of cognitive performance; and 4) faster clinical AD progression once diagnosed with $A D$ (i.e. after point of inflection in Fig 1, called resilience; Stern, 2009).

An individual with higher reserve is predicted to have greater resistance, but less resilience, to $A D$ than an individual with lower reserve. Resistance is defined as an individual's ability to withstand AD-related brain pathology and remain cognitively normal, particularly in relation to a greater risk of developing AD (e.g., older age, presence of APOE4 allele; Montine et al., 2019). Resilience refers to one's ability to sustain cognitive performance in the presence of substantial AD-related pathology (Montine et al., 2019). Evidence indicates that individuals with greater reserve capacity resist diagnosis of $A D$ for longer, maintaining cognitive function despite presence of AD pathology (e.g., Boots et al., 2015; Stern, 2002). Once individuals with higher reserve, and thus greater resistance, succumb to $A D$ there is evidence that the disease progresses more rapidly reflecting lower resilience (Barulli and Stern, 2013; Stern, 2002). To date, little is known of whether there are sex or gender differences in cognitive reserve, resistance, or resilience.

We conducted a literature review in order to determine what is known about women's cognitive reserve throughout the lifespan, and how this may affect women's resistance and resilience to AD. We hypothesized that women accumulate less cognitive reserve across the lifespan according to traditional measures of reserve, but that mitigating factors including gender might suggest other possible contributors to reserve.

\section{Method}

We searched the literature for sex or gender differences in the accumulation of reserve and its effect on the progression of $A D$ using the following databases: Medline, EMBASE, Psyclnfo, PubMed, and Web of Science. In addition, we performed a manual search of the reference lists on Google Scholar for relevant articles not included in those databases. Keywords for our initial search were: "sex differences", "gender differences", "cognitive reserve”, "brain reserve", "reserve”, “Alzheimer's Disease”, "Alzheimer", "AD”. In order to perform a more thorough search of reserve factors, we conducted separate searches to include common contributors to reserve including: IQ, education, occupation, cognitively stimulating activities, bilingualism, SES, physical activity, and social support. We completed these additional searches by replacing 
RUNNING HEAD: Sex differences, cognitive reserve, and Alzheimer's

the reserve key terms (i.e. "cognitive reserve", "brain reserve", and "reserve") with each contributor to reserve that we considered in the review: 1) "IQ" or "intelligence quotient"; 2) "education"; 3) "occupational complexity" OR "occupation"; 4) "cognitively stimulating activities" OR "cognitive stimulation" OR "cognitive activity" OR "cognitive activities"; 5) "bilingualism" OR “multilingualism"; 6) "socioeconomic status" OR "SES"; 7) "physical activity" OR “exercise"; 8) "social support” OR “socialization" OR "marital status".

We did not restrict our search based on the year of publication but did restrict it based on the articles being in English. We removed duplicate entries and using the title and abstract, screened articles to identify eligible studies that considered sex and/or gender differences in reserve or contributors to reserve, and their effect on AD. Articles were included for full text screening if the title or abstract explicitly mentioned sex and/or gender differences in reserve or reserve contributors. If reserve or its contributors were mentioned in the title or abstract but consideration of sex and/or gender were not, we included the article for full text screening to check for any post-hoc analyses of sex/gender. We excluded any articles that covaried for the effects of sex and/or gender or reserve (e.g., years of education) since that would essentially remove those contributors from the analysis.

Articles that remained were read in full to assess inclusion. We included studies in our final analysis if they explicitly used sex and/or gender in their analyses by: 1) stratifying the sample by sex or gender, running the analyses separately for women and men; 2) testing sex and/or gender using interaction terms; or 3) using higher modelling techniques to test the significance of sex and/or gender (Figure 2).

\section{Results}

Based on the above criteria, our search returned 15 studies, which we review below. Two studies directly investigated sex differences in reserve, and 13 studies used the six contributors to reserve: education $(n=8)$, IQ $(n=2)$, and occupational complexity $(n=3$; Table 4). We found no papers that investigated sex differences in the reserve contributors of SES, social support, or physical activity in the risk for AD, nor any papers that investigated gender differences in cognitive reserve.

\subsection{Sex differences in direct measurement of cognitive/brain reserve}

Three studies explicitly stated that the goal was to investigate sex differences in cognitive/brain reserve (Malpetti et al., 2017; Perneczky et al., 2007b; Sundermann et al., 2016b). One study shows that women and men with AD have similar performance on a cognitive battery testing verbal fluency, memory, and 


\section{RUNNING HEAD: Sex differences, cognitive reserve, and Alzheimer's}

visuospatial skills despite men's greater deficits in cerebral metabolism, suggesting that men have greater resilience than women (Perneczky et al., 2007). A second study shows the opposite: in women and men with $\mathrm{MCl}$, women had better verbal memory performance despite equivalent cerebral hypometabolism suggesting that women may have greater resistance in the verbal domain, although this relationship was not observed in healthy older adults or those diagnosed with AD (Sundermann et al., 2016b). It should be noted that despite discussing sex differences in reserve in the context of cerebral metabolism, both Perneczky (2007) and Sundermann (2016b) controlled for years of education in their analyses, suggesting that variability in the data from cognitive reserve accumulated via education was statistically removed. Sex differences in cognitive performance or cerebral glucose metabolism might have been correlated with level of education, which would imply sex differences in reserve accumulation based on education, but this cannot be determined from these studies since education was used as a covariate. One study examined sex differences in cognitive reserve, which was operationalized as education and occupation, on cerebral glucose metabolism. Women and men diagnosed with $A D$ demonstrated positive correlations between years of education and occupational attainment and cerebral glucose metabolism; this was observed in in frontal and limbic regions in women but parietotemporal regions in men (Malpetti et al., 2017). Thus, both sexes benefit from higher reserve as measured by cerebral glucose metabolism, but the brain regions affected by reserve differed between women and men. These results also suggest that early reserve accumulation (via education) benefits women more while mid-life reserve accumulation (via occupation) benefits men more. Taken together, these studies point to sex specific life periods and types of contributors that differentially build functional reserve in women and men.

\subsection{Sex Differences in contributors to cognitive reserve}

Thirteen studies investigated sex differences in the factors thought to contribute to reserve on cognition and/or AD pathology.

\subsubsection{Education}

Years or level of education is the most commonly studied contributor to reserve (Stern, 2006). Studies that explored the effect of education on cognitive ability in adults with $A D$ or with risk factors of $A D$, but did not take sex into account, found that higher level of education was consistently associated with lower prevalence and incidence of AD (for review see Meng and D'Arcy, 2012). We found eight studies that 


\section{RUNNING HEAD: Sex differences, cognitive reserve, and Alzheimer's}

examined sex differences in the effect of education on cognitive reserve in AD. Two studies found that although more years of education was associated with reduced prevalence or incidence of $A D$, the effect of education did not differ between the sexes in either study suggesting that education confers similar reserve capacity to women and men (Fratiglioni et al., 1991; Letenneur et al., 1999, respectively). Similarly, fewer years of education correlated with cerebral hypometabolism in women and men but there were sex differences in the brain regions demonstrating hypometabolism (Malpetti et al., 2017). These studies suggest that education contributes to reserve in both sexes, although underlying neural circuits may differ.

In contrast, other studies indicated that increased education provided greater protection against AD in women but not men. Specifically, women with high education had reduced risk of developing AD compared to women with low/moderate education, a relationship that was not observed in men (Launer et al., 1999; Letenneur et al., 2000). Furthermore, in individuals who did not carry the APOE4 allele, more years of education was associated with slower declines in Mini Mental Status Exam (MMSE) score with age in women but not men (Oliveira et al., 2016). In APOE4 carriers, more years of education was associated with slower cognitive decline, measured by the Cognitive Dementia Rating Scale, in women but not men (Oliveira et al., 2016). Lastly, CSF levels of amyloid beta at baseline predicted more rapid decline in executive function in women compared to men (Koran et al., 2017). These effects were most pronounced in women with fewer years of education suggesting that education allows women to maintain executive function in the face of $A D$ pathology. Additionally, although Fratiglioni et al. (1991) did not observe a sex difference in the effect of education on $A D$ prevalence in their sample, when participants with vascular dementia and AD were grouped together lower level of education significantly increased dementia risk in women but not men. Similarly, Letenneur et al. (1999) did not observe sex differences in education and incidence of AD, but when they augmented their sample using other European test sites, they found that lower education predicted AD in women but not men (Letteneur et al., 2000). Taken together, these results indicate that higher education may be more critical to women's cognitive reserve than to men's and that higher education for women may help decrease the risk for AD.

Only one study observed that education conferred greater protection against AD in men than women. Men with AD had significantly better performance on the MMSE than women of the same age with the same level of education (Pradier et al., 2014). Differences in sample characteristics, sample sizes or other reserve factors that are associated with education (i.e. occupational complexity and SES) may contribute to these studies not matching other research on sex differences in how education modifies risk of AD diagnosis. 
RUNNING HEAD: Sex differences, cognitive reserve, and Alzheimer's

When these results are considered together, they suggest that education may affect reserve capacity in women more than men since higher education confers greater protection against developing AD and cognitive decline in old age, even in the face of $A D$ pathology. However, there are contradictory findings so more research on this is warranted. In spite of the fact that in all the papers where sex differences in years or level of education were assessed, men had higher rates of education than women (Letenneur et al. 1999; Letenneur et al. 2000; Malpetti et al., 2017), women still benefitted more from higher levels of education suggesting that education level is critical to women's resistance.

It should be noted that although education as a reserve factor is often measured from early life (i.e. high school and undergraduate programs are completed in young adulthood), in men, training in the workforce later in life can compensate for an initial low level of education resulting in equivalent cognitive performance to individuals with high levels of education (Wight et al., 2002). We are not aware of any studies that have explored this with respect to sex differences or in women.

\subsubsection{Intelligence Quotient (I.Q.)}

IQ aims to measure crystallized general intelligence and is frequently used as a contributor to cognitive reserve. IQ is measured using a wide range of standardized tests (i.e., Wechsler Adult Intelligence Scale, Wide Range Achievement Test, National Adult Reading Test). Depending on the test used, IQ can be derived from calculating participants' ability to read (e.g., pronounce a list of words ranging in difficulty), understand sentences, spell, reason abstractly, and/or solve math problems. In studies of AD patients that do not consider sex, higher estimates of premorbid IQ have been linked to reduced dementia severity (Maddrey et al., 1996), better MMSE performance (Osone et al., 2015), higher cerebral glucose metabolism (Alexander et al., 1997), and larger hippocampal volume (Lo et al., 2013; Osone et al., 2015). In all of these studies, premorbid IQ was estimated using verbal reading tests after patients were diagnosed with AD (e.g., Wide Range Achievement Test, National Adult Reading Test). Although reading tests have been established as reliable measures of premorbid IQ (Bright and van der Linde, 2020), many studies also account for the effect of dementia severity in their analyses (e.g., Alexander et al., 1997; Osone et al., 2015).

We found two studies that looked at sex differences in the relationship of IQ to episodic memory performance in a sample of $\mathrm{MCl}$ and $\mathrm{AD}$ patients. Higher composite IQ scores and greater academic achievement during adolescence (i.e., high school) predicted lower incidence of AD in both women and men; the odds ratios were almost identical indicating that IQ benefits the sexes equally (Huang et al., 2018). 


\section{RUNNING HEAD: Sex differences, cognitive reserve, and Alzheimer's}

However, the situation is more complicated when premorbid IQ is estimated in AD patients using the German vocabulary test (Wortschatztest, WST). In a sample of AD patients split into four groups based on sex and IQ (low $<100$ vs. high $>100$ ), all four groups performed similarly on a verbal episodic memory task, but men in both IQ groups performed better on the delayed component of a visuospatial episodic memory task than women (Beinhoff et al., 2009). Specifically, high IQ women had elevated CSF tau compared to high IQ men, possibly suggesting greater preservation of brain reserve in regions mediating visuospatial episodic memory task in men which may be compromised in women. However, in the low IQ groups the CSF tau levels were similar for women and men but women had worse visuospatial memory suggesting that IQ benefits cognitive reserve for visuospatial episodic memory function more in men. Interestingly women in the high IQ group performed better on the visuospatial task than women in the low IQ group suggesting IQ does benefit cognitive reserve in women, but possibly less than in men. The results of these studies are mixed indicating that higher adolescent IQ reduces $A D$ risk equally in men and women, but that measures of premorbid IQ in $A D$ patients indicate that IQ may benefit reserve more in men than women.

\subsubsection{Occupational Attainment}

Occupational attainment is thought to reflect occupational complexity, another contributor to cognitive reserve (e.g., Boots et al., 2015). In addition to collecting data about the participant's occupation, occupation complexity can be coded in terms of work with data, people, and/or things (Sörman et al., 2019). In studies that did not disaggregate their analyses by sex, different components of occupational complexity, such as decision latitude (autonomy to make decisions at your job instead of deferring to a supervisor), interactions with people, and data management were associated with reduced risk of developing late onset AD (Dekhtyar et al., 2016; Smart et al., 2014; Wang et al., 2017). Higher occupational complexity in interpersonal and data management realms was also associated with higher scores of general cognitive ability, memory, and processing speed (Boots et al., 2015; Smart et al., 2014), suggesting that occupation may help delay $A D$ onset. In a traditional sense of work outside the home, men have held more complex occupations than women (Mielke et al., 2014). In the few recent studies that have examined this, evidence from both Swedish and Scottish cohorts of older adults demonstrates that in work outside the home, men still have access to higher occupational complexity than women (Finkel et al., 2009), particularly in fields working with data. Although there are exceptions, the benefits of occupational complexity may accrue primarily to men. 


\section{RUNNING HEAD: Sex differences, cognitive reserve, and Alzheimer's}

We found three studies that stratified their analysis of occupation by sex. The general findings of these papers were mixed. In one study, the age and sex adjusted primary analysis revealed that manual work (presumably lower complexity) was significantly associated with greater risk of developing AD, compared to non-manual work (Qiu et al., 2003). However, the authors found sex differences in the type of manual work (i.e., manual work in general, manual work involving goods production or service production) and its risk for AD. In men, there was no significant association between general or manual work involving goods production and the risk of developing AD. In contrast, in women manual work involving goods production was associated with a higher risk of developing $A D$. There was also a lower risk of developing $A D$ and manual work involving goods production across both sexes in the higher education ( $>8$ years) vs. the lower education group (<8 years) and in the older age group ( $\geq 85$ years) compared to the 'younger-old' age group (75-84 years). Interestingly, the authors suggested that environmental circumstances may have contributed to the elevated risk of $A D$ diagnosis associated with manual work involving goods production. They note that industrial changes that occurred after the 1950s could have resulted in an increased exposure to industrial pollutants related to increased $A D$, which may have affected the younger-old individuals when baseline examination was performed (1987-89). In addition, many of the jobs that fall under the category of manual work involving goods production (e.g., mechanical technicians, welders, metal workers) generally involve exposure to multitoxins, which may have contributed to the elevated likelihood of AD diagnosis. Lastly, the authors speculated that manual work is related to low income, which may be associated with poorer living conditions (e.g., in housing, nutrition, and social environment) and engaging in unhealthy behaviours (e.g., excessive smoking, alcohol intake) contributing to elevated AD pathology (Dartigues et al., 1992; Engelhart et al., 2002; Fratiglioni et al., 2000, 1993; Merchant et al., 1999; Moceri et al., 2000; Morris et al., 2002; Ott et al., 1998; Scarmeas et al., 2001). Thus, this study suggests that complexity of work may reflect the conditions rather than the mental challenges and that it is more likely the conditions of the work that contribute to cognitive decline.

In the second study, Helmer et al (2001) found that although the global effect of occupational categories did not confer protection in mixed sex analyses, when they stratified by sex women exhibited greater resistance than men to developing AD if they were crafts workers and shopkeepers. In men these occupational categories increased risk of developing AD (Helmer et al., 2001). These authors also suggest that differences in health behaviour and exposure to environmental factors, which may be linked to the type of occupation, may contribute to elevated risk of dementia generally. Thus, investigating the relationship 


\section{RUNNING HEAD: Sex differences, cognitive reserve, and Alzheimer's}

between occupational attainment and risk of developing $A D$ is complicated by the conditions of the work environment as well as the different health behaviors of women and men.

A last study challenged the idea that occupation had to be 'outside the home.' In a large sample of women and men ( $n=1722$ men; 2161 women), Santabarbara and colleagues (2019) found that for women and men, being a farmer conferred greater AD protection than other occupation categories (white-collar, blue-collar, homemaker). In women, being a farmer was more protective against developing AD than being a homemaker. Being a homemaker, in turn, was related to greater likelihood of living alone, having depression, hypertension and obesity (i.e., general health moderators associated with greater likelihood of AD diagnosis) than any other occupation category. All individuals from the homemaker category $(n=1407)$ in this study were women. The authors theorized that being a farmer conferred greater protection, in part, because of the environmental circumstances in which the participants were born. Their Spanish cohort was born at the start of the 20th century and lived through the Spanish Civil War and post-war years. The war-related stress and nutritional deficits may have had a greater impact to city inhabitants (who were usually blue-collar workers) as opposed to farmers' families, who had better access to nutrition during the war compared to urban dwellers. Thus, occupational attainment in the studies explicitly disaggregating their data by sex suggest that 1) jobs thought to be just manual labor (farming) may have very complex attributes and 2) the conditions of work, as well as complexity, contribute to cognitive reserve.

\subsubsection{Cognitively Stimulating Activities}

In cohorts that don't distinguish between women and men, cognitively stimulating leisure activities in old age (i.e. skill based games and crossword puzzles, and social activities) also contribute to reduced risk of developing $A D$, suggesting that reserve can be accumulated or at least maintained into old age in individuals engaging in those activities (Boots et al., 2015; Smart et al., 2014; Wang et al., 2017). In a sample of AD patients from the Cache County Study on Memory in Aging, a higher number of cognitively stimulating activities per week predicted slower cognitive decline measured by the MMSE over a one-year period (Treiber et al., 2011). They noted that men participated in significantly more cognitively stimulating activities than women. However, they covaried sex in their analyses without reporting whether sex affected their model, so it is unclear whether cognitive activities had different effects in women and men. The beneficial effect of cognitive stimulation was strongest in those with the shortest duration of $A D$, indicating that it is important to engage in these activities as early as possible (Treiber et al., 2011). 
RUNNING HEAD: Sex differences, cognitive reserve, and Alzheimer's

We found no studies examining sex differences in the beneficial effects of cognitively stimulating activities. Further research is needed to determine whether cognitive activity in midlife and old age benefit reserve differently in women and men.

\subsubsection{Bilingualism}

Studies that do not disaggregate their data by sex reveal that bilingualism has the potential to increase resistance, delaying AD onset by 4-5 years (Bialystok et al., 2007; Perani and Abutalebi, 2015). Bialystok and colleagues used sex as a covariate in their primary analysis to determine if bilingualism delayed $A D$ onset (Bialystok et al., 2007), but subsequent analyses to determine if there was a difference in monolinguals seeking medical attention longer than bilinguals. The authors found that generally, men delayed clinic visits longer than women, and monolingual males were slower to seek medical attention than any other group (Bialystok et al., 2007). Thus, although bilingualism may delay AD onset, it was difficult to determine whether there was a sex difference in bilingualism and reserve.

We found no studies that looked at sex differences in the effects of bilingualism on cognitive reserve in AD. One study, however, did investigate sex differences in the role of bilingualism on preventing any kind of dementia onset (Alladi et al., 2013). The cohort consisted of 424 men and 224 women with dementia (37\% AD) from Hyderabad, India. There was no significant interaction between sex and bilingualism on the age of onset for dementia. However, this sample had significantly more men than women and participants were diagnosed with various forms of dementia which makes it difficult to determine how sex differences in bilingualism affect $A D$ onset specifically. Another study of mixed sex found that multilinguals who spoke four or more languages were diagnosed with $A D$ at a later age than those who spoke fewer than four languages. Sex was used as a covariate in primary analyses eliminating any effects of sex. However, women were more represented in the monolingual group and thus the trend for men to be diagnosed at a later age than women supports the idea that multilingualism delays AD (Chertkow et al., 2010).

\subsubsection{Socioeconomic Status (SES)}

Low socioeconomic status (SES), often assessed as a combination of education, occupation, and income (Darin-Mattsson et al., 2017), is linked to poorer health leading to earlier mortality (Matthews and Gallo, 2010) and increased risk of AD (Karp et al., 2004). It is hypothesized that low SES increases stress 


\section{RUNNING HEAD: Sex differences, cognitive reserve, and Alzheimer's}

because of greater financial strain, exposure to physical strain from living in areas with elevated chemical and noise pollution, and unavailability of a nutritious diet (Cohen et al., 2010; Evans and Kim, 2010).

We found no studies that looked at whether SES affected cognitive reserve to impact risk of AD differently in men and women. However, one study investigated sex differences in the ability of SES (measured by education and occupation) to mitigate risk for dementia in people carrying the APOE4 allele (Hasselgren et al., 2019). In a sample of 580 women and men from the H7O Birth Cohort Study and the Prospective Population Study on Women, high SES (a white-collar occupation and higher educational attainment) delayed dementia onset even in men carrying an APOE4 allele. However, women with high SES (white-collar occupation) carrying the APOE4 allele developed dementia earlier than women with high SES who did not carry an APOE4, at a similar age to women with low SES (blue-collar occupation). AD onset in women with low SES (blue collar women) was unaffected by the APOE4 allele. Higher educational attainment did not seem to particularly benefit women: both women with the highest (i.e., secondary/university) and lowest levels (i.e., primary) of education had shorter time to disease onset than women with lower-secondary education. Thus, the one study that investigated sex differences in the SES-dementia relationship showed clear advantages of SES in delaying dementia in men, but not in women (Hasselgren et al., 2019). One limitation is that SES in this study was largely defined as the participants' education and occupation, so other measures indicative of SES (e.g., income, characteristics surrounding their living situation, etc.) were not considered.

Another study on SES and general dementia highlights the complexity of proxies for SES. While there was no association between low neighbourhood SES (measured via neighbourhood composition, e.g., affluent vs. disadvantaged) and dementia in men, there was for women. Women with lower neighbourhood SES (i.e., highest unemployment rate, greater proportion of tenant occupancy) had higher risk of dementia. In this sample, women were more often widowed than men, had lower education, lower income, and lived alone more than men (Letellier et al., 2018). Thus, 'low SES' for women was associated with negative health factors and lower access to reserve contributors than 'low SES' for men. It is important that future work consider the different factors that enter into SES for women and men since it is important to disentangle the effect of differential contributors to reserve, education and occupation. 


\section{RUNNING HEAD: Sex differences, cognitive reserve, and Alzheimer's}

\subsubsection{Physical Activity}

In mixed sex studies, increased physical activity is associated with better cognitive performance for both women and men (Guiney and Machado, 2013). For example, frequency of weekly physical activity is positively correlated with motor reaction time and attention (measured by the Eriksen Flanker Task) in both younger and older adults, and accuracy in older adults (Hillman et al., 2006). Although exercise benefits cognition across the lifespan it seems to be particularly beneficial for older adults (Barha and Liu-Ambrose, 2018). Higher levels of physical activity are linked to decreased pathology associated with aging and AD (Brown et al., 2019). Specifically, physical activity is associated with increased cerebral blood flow (Guiney et al., 2015), increased anterior hippocampal volume (Erickson et al., 2011), decreased cortical tau burden (Brown et al., 2018), and less age-related decrease in cerebral glucose metabolism and increase in cortical $\beta$-amyloid deposition (Okonkwo et al., 2014). However, none of these studies stratify their data by sex.

We found no studies that investigated whether physical activity affected the risk of developing AD differently in women and men. However, two meta analyses of intervention trials with healthy older adults demonstrate that cohorts with higher percentages of women consistently have a larger effect size, suggesting that women's reserve benefits more from exercise than men's (Barha et al., 2017; Colcombe and Kramer, 2003). The same is the case in studies of $\mathrm{MCl}$; aerobic exercise training programs improve performance on more measures of executive function in women compared to men (Baker et al., 2010). They also improve attention and memory performance in women while only improving memory in men (Van Uffelen et al., 2008). Thus, women's reserve seems to benefit more from physical exercise whether this is through resistance or resilience remains to be determined. Unfortunately, women in middle to old age have lower levels of physical activity than men internationally (Canadian cohorts: Kaplan et al., 2001; US cohorts: Lee, 2005; and Korean cohorts: Lee et al., 2017). This suggests that ultimately physical activity will play a lesser role in women's cognitive reserve than men's because women are less physically active. This could be viewed as a gendered effect on reserve as gender norms have dictated that women exercise less. Less exercise in women may also raise their rates of obesity which, in itself, is a risk factor for AD (Table 3).

\subsubsection{Social Support}

In general, social support is thought to contribute to cognitive reserve because it reduces feelings of loneliness that are associated with an increased risk for dementia (Holwerda et al., 2014). In this same vein, 


\section{RUNNING HEAD: Sex differences, cognitive reserve, and Alzheimer's}

unmarried or single people are at greater risk of developing AD than married individuals (Helmer et al., 1999; Sundström et al., 2016).

We found no studies that compared the effect of social support in women and men on the likelihood of developing AD. One study with 600 AD patients (214 men; 386 women) that disaggregated their data by sex noted that women reached greater than $50 \%$ loss of autonomy (but not in need of 24-hour care or institutionalization) more quickly than men (Sinforiani et al., 2010). The authors speculated that this may partly be because more women in their cohort lived alone, but this was not tested directly. While women may enjoy more social support than their male peers in youth and middle age, this earlier social support does not seem sufficient to stave off earlier dependence in women. In studies that look at dementia in general, divorced men are at greater risk of developing dementia than divorced women (Sundström et al., 2016) and never married or widowed men have a greater risk of developing dementia compared to women (Pankratz et al., 2015).

Two gender norms, social support and caregiving, may intersect to protect women against the toll of caregiving. Several studies have found that being a caregiver for someone with dementia compromises caregiver health and well-being (Brodaty and Donkin, 2009; Richardson et al., 2013). When data are disaggregated by sex, husbands who are caregivers are at greater risk for developing dementia than caregiving wives, suggesting that women may effectively find protection in other social ties or an earlier history of social support, while men may not find such ties outside of their marriage (e.g., Dykstra \& Gierveld, 2014). Theoretically, since women are more likely to seek social support than men (Billings and Moos, 1981; Folkman and Lazarus, 1980; Hamilton and Fagot, 1988; Stone and Neale, 1984) one would think that social support would be a larger contributor to women's cognitive reserve (Evans et al., 2018). However, based on the dearth of studies in women, further research examining sex differences in social support are required to understand how different kinds of social support would mitigate against AD pathology. It is possible that, because women spend greater time caring for loved ones than men, women experience a greater toll of caregiving for women. This reinforces the necessity to look at how different contributors to cognitive reserve intersect and how gender norms influence these reserve contributors to affect each sex differently.

\section{Discussion}

We reviewed the literature on sex differences in factors that contribute to cognitive reserve. Out of 63 articles that met the screening criteria, only 15 met screening criteria, including an analysis of women or sex 


\section{RUNNING HEAD: Sex differences, cognitive reserve, and Alzheimer's}

differences. The elevated rate of AD diagnosis in women and their more rapid cognitive decline once diagnosed with $A D$ in concert with hormone deprivation at menopause - known to worsen general health moderators (i.e. mood disorders, sleep, inflammation) - may reduce reserve capacity as they enter older adulthood (Irvine et al., 2012; Laws et al., 2018). However, despite the cognitive reserve literature having the potential to contribute to an understanding of sex differences in the risk for $A D$, there is very limited research examining sex differences in reserve or reserve in women. Further, we found no studies that specifically investigated gender differences in reserve, although some of the contributors to reserve may be gendered. This suggests that while reserve contributors have been assumed to apply to both sexes, we really do not know that they do or, whether they affect both sexes to the same extent.

Of the three studies that directly examined sex differences in cognitive reserve at the functional level, those using cerebral glucose metabolism as an indicator of reserve have complicated results, suggesting that one size does not fit all. Men with AD exhibit similar performance on a cognitive battery compared to women with AD despite having greater hypometabolism, suggesting men have more resilience than women (Perneczky et al., 2007). However, in specific cognitive domains (e.g., verbal), although there were no sex differences in verbal ability in the $\mathrm{AD}$ sample, in the $\mathrm{MCl}$ sample: women perform better than men despite having similar levels of hypometabolism, suggesting women have more resistance than men (Sundermann et al., 2016b). When the direct effect of reserve contributors (i.e. education and occupation) on cerebral glucose metabolism were assessed, they suggested that different brain circuits may underly reserve (Malpetti et al., 2017). Due to the lack of studies, we could not draw conclusions about sex differences in reserve from contributors including bilingualism, physical activity, cognitively stimulating activities, SES, and social support. However, except for social support, the historical accessibility and social acceptance of these other reserve factors has been far greater for men than in women. In domains where women's reserve seems to benefit more - education and physical activity - gender norms seem to mitigate their engagement in these activities and consequently, women have less opportunity to accumulate reserve from these. However, if women had the same opportunities to engage in these factors, extant literature suggests they would benefit women's reserve possibly more than men's.

Our review suggests that when women have higher contributors to reserve, women gain more resistance to $A D$ onset, compared to men. However, these factors do not seem to contribute to resilience in women following $A D$ diagnosis. For example, generally higher education provides greater resistance in women than in men (Launer et al., 1999; Letenneur et al., 2000). However, once diagnosed with AD, men have greater 


\section{RUNNING HEAD: Sex differences, cognitive reserve, and Alzheimer's}

resilience than women despite similar levels of education (Perneczky et al., 2007; Pradier et al., 2014; but see Malpetti et al., 2017). In terms of IQ, although we found no studies that examined sex differences in resistance, one study demonstrated that higher IQ provides men greater resilience than women on the visuospatial episodic memory task (Beinhoff et al., 2009). Finally, 'higher occupational attainment' did not necessarily confer greater resistance or resilience in either sex. Instead, the type of occupation had to be considered in the context in which the occupation was held (e.g., availability to nutrition, resources, presence of war, exposure to toxins). Extant studies suggest that having certain jobs with healthy working conditions (e.g., crafts worker, shopkeeper, farmer) confers greater resistance in women than men, particularly in comparison to other jobs that women held (e.g., homemaker; Helmer et al., 2001; Santabarbara et al., 2019; but see Qiu et al., 2003). Finally, although higher SES (measured by occupation type) was dementia-protective to men independent of APOE4 status, higher SES provided less protection to women if they carried the APOE4 allele (Hasselgren et al., 2019). This suggests that contributors to reserve need to be considered in the context of $A D$ risk factors, biological sex, gender, and their intersections.

Our review reveals that social support may contribute to more resistance in women than men because women engage in more social factors, such as seeking greater social support and more regular medical attention (Billings and Moos, 1981; Dykstra and Gierveld, 2014; Hamilton and Fagot, 1988; Shye et al., 1995), which may increase reserve. Men have a greater risk of developing dementia compared to women if they have never married or are widowed (Pankratz et al., 2015) and although women are more likely to be caregivers than men, male caregivers are at 3x higher risk of developing dementia than women (Norton et al., 2010). These data suggest that a lack of spousal support and caregiving stress increases the likelihood of AD diagnosis in men more than women, possibly due to lack of other social supports. In one study, all 1407 participants in their 'homemaker' occupation category were women; these women were more likely to live alone and have depression than participants from any of the other occupation types (Santabarbara et al., 2019). These findings highlight the importance of also considering social support in the context of one's occupation type and how that might also protect against AD. Just as risk factors and general health moderators compound in complex ways, reserve factors can also work in multiplicative ways to increase reserve and hence, resistance to $A D$.

In spite of the paucity of sex difference studies in cognitive reserve, some findings from this review suggest that although the rate of $A D$ is higher in women than men, there may be a subgroup of women that have high resistance to AD than men, potentially because of increased accumulation of reserve. 
RUNNING HEAD: Sex differences, cognitive reserve, and Alzheimer's

Supporting this is research that indicates sex differences in the incidence of AD are specific to the cohort's age (Andersen et al., 1999; Brayne et al., 1995; Fratiglioni et al., 1997; Letenneur et al., 1999; Miech et al., 2002; Ott et al., 1998; Ruitenberg et al., 2001). For example, once diagnosed with $\mathrm{MCl}$, the rate of progression to $A D$ at 70-79 years is greater in men than women but at >80 years, higher in women than men (Roberts et al., 2012). By segregating individuals according to whether they are older or younger than 80 years, the findings reveal a survival bias in the older women, with later age of onset suggesting they may be resistant to AD.

This survival bias within women is further supported by the Alzheimer's Disease Neuroimaging Initiative (ADNI) cohort of women and men with $\mathrm{MCl}$. Measuring CSF tau/A $\beta$ levels to divide women and men according to whether they had " high" or "low likelihood" of progressing to AD led to the finding that "high likelihood" women had significantly faster cognitive decline than "low likelihood" women, while high and low likelihood men did not differ in the rate of their cognitive decline (Sohn et al., 2018). Importantly, these studies demonstrate that there are two populations of women, one with more resistance to AD. Thus, the resistant group is an important one to study to better understand the factors contributing to their later onset of $A D$, including those contributing more generally to cognitive reserve in women.

Further evidence suggests that if women can resist cognitive decline during early, older adulthood, this may minimize the effect of $A D$ risk factors that disproportionately affect women, such as carrying an APOE4 gene (Bretsky et al., 1999a; Corder et al., 1993; Gómez-Tortosa et al., 2007). A meta-analysis found that women have an elevated risk of developing AD between the ages of 65 and 75 if they have the APOE-e3/e4 genotype, but that there are no sex differences in APOE4 risk prior to 65yrs or after 75yrs, suggesting a potential critical period in which women could defray their increased risk of AD (Neu et al., 2017). Thus, maintaining health during middle age and across the menopause transition might buffer against cognitive decline during this critical period in a woman's life when there is elevated risk of progressing to AD.

If cognitive decline can be resisted during this critical period, women may fare better than men. In healthy aging, men demonstrate faster rates of cognitive decline in key cognitive domains than women (McCarrey et al., 2016). For example, older women tend to perform better than older men on episodic memory (a domain affected in early stages of AD; Asperholm et al., 2019; Herlitz and Rehnman, 2008; Jack et al., 2015), and have lower age-related declines in brain volume than men (Jack et al., 2015; Pfefferbaum et al., 2013). Again, these suggest that some women have greater resistance to $A D$ than men. More direct support of women's elevated resistance comes from studies observing better performance in women than men on a delayed verbal memory task (Rey Auditory Verbal Learning Test) despite having similar hippocampal atrophy, 


\section{RUNNING HEAD: Sex differences, cognitive reserve, and Alzheimer's}

glucose hypometabolism, and $\beta$-amyloid accumulation (Sundermann et al., 2016a, 2016b, 2018). This clearly demonstrates that women are able to maintain verbal memory across the lifespan better than men indicating greater resistance to AD. Interestingly, in this series of studies, the men had significantly higher education level than women, suggesting that education may not confer as strong resistance in men as women, as per studies presented earlier (Koran et al., 2017; Launer et al., 1999; Letenneur et al., 2000; Oliveira et al., 2016).

This subgroup of women who are able to resist $A D$ diagnosis until older age (>80yrs) has sometimes been attributed to sex differences in longevity and differential mortality (e.g., Brayne et al., 1995), but it may not be as simple as that. First, the effect is observed in studies that account for sex differences in longevity by adjusting for age in their models (Andersen et al., 1999; Corrada et al., 2008; Ott et al., 1998; Ruitenberg et al., 2001). In addition, although there is a tendency for women to live longer, in many of these studies, there were no sex differences in the participants who were ultimately excluded due to loss of interest or death (Andersen et al., 1999; Corrada et al., 2008; Ruitenberg et al., 2001), meaning there was no longevity bias favouring women.

As noted, many of the contributors to reserve are highly gendered, including education, occupation, physical activity, and social support. The majority of participants in studies on AD were born in the early- to mid-1900s, when, because of gender norms, reserve factors such as education, occupation, and physical activity were pursued by men, but not women. For example, in this review, most cohorts included women and men whose formative years would have been $1915-1955$, generations in which men had higher education than women (Letenneur et al., 2000, 1999; Malpetti et al., 2017; Sundermann et al., 2016b). It would have also been a time when men who were working would have had jobs with higher occupational complexity compared to the jobs of women (Mielke et al., 2014). Critically, modernization has affected many of these gendered factors to potentially allow for greater reserve accumulation in the next generation of aging women. Education has steadily increased for women in many societies over the past 25 years, and currently more women obtain a four-year university degree than men in both the United States (Duffin, 2019) and Canada (Statistics Canada, 2015). This increase in women's education, and thus occupational attainment, should theoretically increase women's accumulation of reserve, and contribute to the decreased magnitude of the sex difference in AD observed in some American studies (Mielke et al., 2014). Therefore, it is important to incorporate such characteristic differences in generations, including changes in economic, political, environmental, and social landscapes that may impact our understanding of sex differences in cognitive 


\section{RUNNING HEAD: Sex differences, cognitive reserve, and Alzheimer's}

reserve. For example, measuring social progress indicators and/or living conditions may be relevant to incorporate in analyses of sex differences in cognitive reserve (Asperholm et al., 2019).

However, although women have been engaging in more reserve contributors as societies modernize, some gender-typical roles still fall under the responsibility of women to a greater extent than men. For example, women make up 2/3 of caregivers for individuals with AD (Association, 2019). In addition, caregivers for those with dementia are more likely to develop dementia themselves (Norton et al., 2010), requiring that women have yet more reserve to offset this risk. In fulfilling caregiving responsibilities, women are more likely to report negative symptoms of loneliness than caregiving men (Beeson et al., 2000). Coupled with women's susceptibility to depression (Liming Alspaugh et al., 1999; Rose-Rego et al., 1998; Russo et al., 1995; Schulz et al., 1992), this could worsen general health and increase the risk of developing AD for women, perhaps beyond what reserve can mitigate. This could potentially contribute to the subset of women at risk for AD in early, older adulthood.

Further supporting gender norms, many of the contributors to reserve underplay the complexity of tasks involved in more female-typical occupations, such as farm wife. For example, "farm wife" may not adequately capture the complexity of managing the finances and resource planning for the farm, socializing with family members, caregiving for children and elderly parents, and managing daily household tasks. Thus, what might be considered low occupational attainment and hence, complexity, may actually be relatively complex and contribute to accumulation of reserve capacity. In fact, being a farmer contributed to reserve in both women and men (Santabarbara et al., 2019). Thus, to prevent gender bias while investigating reserve, future work should seek to consider less gendered measures of reserve to better capture women's ability to resist $A D$.

When women do engage in many of these reserve factors, it benefits them substantially, sometimes more than they benefit men. Selective survival may be occurring in this subset of women who engage in reserve factors that increase resistance in women more than men. Although our review did not find studies that considered sex differences in all of the reserve factors considered, studies do demonstrate the importance of education (Letteneur et al., 2000, Oliviera et al., 2016, Koran et al., 2017, Launer et al., 1999), bilingualism (Subramaniapillai et al., 2018), and physical activity (Baker et al., 2010; Barha et al., 2017; Colcombe and Kramer, 2003; Van Uffelen et al., 2008) to women's resistance to age-related cognitive decline.

Importantly, this review reveals that cognitive tasks with known sex differences in performance (visuospatial tasks in men; verbal tasks in women) tend to mark resistance/resilience in the sex they favour. 
RUNNING HEAD: Sex differences, cognitive reserve, and Alzheimer's

Since many of the tasks used to assess memory have a verbal component, on which women typically perform better, they may favour resistance in women. Thus, it is critical that future work consider this differential effect of resistance in women and men based on the specific cognitive task employed and whether women or men may be already advantaged in the faculties that the task assesses. For example, IQ is often assessed by measuring a participant's verbal ability, as per Beinhoff (2009) that assessed IQ via a German vocabulary test (Beinhoff et al., 2009). One might expect that since this requires verbal ability, the test would favor women in that they would perform as well as men with more cognitive reserve. And, indeed, the authors found no sex differences in the effect of IQ on verbal memory. Further, they found that low IQ men outperformed women on visuospatial episodic memory. Thus, future psychometric measures that aim to capture contributors to reserve should consider using non-verbal tasks to assess reserve or using verbal ability/memory as a covariate of interest (Sundermann et al., 2019).

In sum, our review of the literature on sex/gender differences in cognitive reserve in $A D$ reveals that a) the literature is very sparse and b) when analyses are stratified by sex they reveal opportunities for women to increase reserve capacity, possibly reducing their risk for AD. Historically these opportunities have been hampered by social norms of gender, but represent an opportunity for interventions which might reduce sex differences in the rate of $A D$ if women engage with these reserve contributors. This review also highlights the need to look at intersections between different reserve contributors, and their interactions with health moderators, since these can have multiplicative effects. It is critical to understand what contributes to the increased resistance to $A D$ observed in a subset of women, including better understanding of sex differences in cognitive reserve, to maximize healthy aging in women and men.

\section{Conclusions}

Given the sparsity of the extant publications on sex differences in reserve in $A D$, it is important that future research consider both sex and gender in reserve through appropriate analyses. They should report whether or not such analyses were conducted and, even null findings. Sex stratified analyses and gender considerations are critical not only to reveal different AD-related mechanisms in women and men, but also in finding the most efficacious interventions for each sex. In addition to widening the types of activities viewed as contributors to cognitive reserve, it is critical to begin to integrate and welcome into research participants with a diversity of backgrounds including, sexual and gender identities as well as ethnicities and social positions. Wider inclusion of diverse peoples will increase our understanding of the key components 
RUNNING HEAD: Sex differences, cognitive reserve, and Alzheimer's

contributing to cognitive reserve for each group. Integrating sex and gender in our investigations of cognitive reserve, resistance, and resilience to $A D$ could better inform health interventions and social policies that aim to reduce the burden of $A D$ among women and men.

\section{Declarations of interest: None}

\section{Acknowledgements:}

This work was supported by the Wilfred and Joyce Posluns Chair in Women's Brain Health and Aging (the Women's Brain Health Initiative, Ontario Brain Institute, and the Canadian Institutes of Health Research, awarded to G. Einstein); the Canadian Institute of Health Sciences Project grant PJT 153321 and the Natural Science and Engineering Research Council RGPIN-2018-05761 (awarded to M. N. Rajah); the Alzheimer's Society Postdoctoral Fellowship for the Posluns Chair (awarded to A. Almey); and the Natural Science and Engineering Research Council Graham Bell Canada Graduate Scholarship-Doctoral (awarded to S.

Subramaniapillai). 


\section{References}

Alexander, G.E., Furey, M.L., Grady, C.L., Pietrini, P., Brady, D.R., Mentis, M.J., Schapiro, M.B., 1997. Association of premorbid intellectual function with cerebral metabolism in Alzheimer's disease: Implications for the cognitive reserve hypothesis. Am. J. Psychiatry. https://doi.org/10.1176/ajp.154.2.165

Alladi, S., Bak, T.H., Duggirala, V., Surampudi, B., Shailaja, M., Shukla, A.K., Chaudhuri, J.R., Kaul, S., 2013. Bilingualism delays age at onset of dementia, independent of education and immigration status. Neurology 81, 1938-1944. https://doi.org/10.1212/01.wnl.0000436609.20587.65

Altmann, A., Tian, L., Henderson, V.W., Greicius, M.D., 2014. Sex modifies the APOE-related risk of developing Alzheimer disease. Ann. Neurol. 75, 563-573. https://doi.org/10.1002/ana.24135

Andersen, K, Launer, L.J., Dewey, M.E., Letenneur, L., Ott, A., Copeland, J.R., Dartigues, J.F., Kragh-Sorensen, P., Baldereschi, M., Brayne, C., Lobo, A., Martinez-Lage, J.M., Stijnen, T., Hofman, A., 1999. Gender differences in the incidence of AD and vascular dementia: The EURODEM Studies. EURODEM Incidence Research Group. Neurology 53, 1992-7. https://doi.org/10.1212/wnl.53.9.1992

Andersen, K., Launer, L.J., Dewey, M.E., Letenneur, L., Ott, A., Copeland, J.R.M., Dartigues, J.F., Kragh-

Sorensen, P., Baldereschi, M., Brayne, C., Lobo, A., Martinez-Lage, J.M., Stijnen, T., Hofman, A., 1999.

Gender differences in the incidence of $A D$ and vascular dementia: The EURODEM Studies. Neurology 53, 1992-1997. https://doi.org/10.1212/wnl.53.9.1992

Asperholm, M., Nagar, S., Dekhtyar, S., Herlitz, A., 2019. The magnitude of sex differences in verbal episodic memory increases with social progress : Data from 54 countries across 40 years. PLoS One 14, 1-11. Association, A., 2019. 2019 Alzheimer's disease facts and figures. Alzheimer's Dement. 15, 321-387.

https://doi.org/10.1016/j.jalz.2019.01.010

Bailly, L., David, R., Chevrier, R., Grebet, J., Moncada, M., Fuch, A., Sciortino, V., Robert, P., Pradier, C., 2019. Alzheimer's disease: Estimating its prevalence rate in a French geographical unit using the National Alzheimer Data Bank and national health insurance information systems. PLoS One 14, e0216221. https://doi.org/10.1371/journal.pone.0216221

Baker, L.D., Frank, L.L., Foster-Schubert, K., Green, P.S., Wilkinson, C.W., McTiernan, A., Plymate, S.R., Fishel, M.A., Watson, G.S., Cholerton, B.A., Duncan, G.E., Mehta, P.D., Craft, S., 2010. Effects of aerobic exercise on mild cognitive impairment: A controlled trial. Arch. Neurol. 67, 71-79.

https://doi.org/10.1001/archneurol.2009.307 
RUNNING HEAD: Sex differences, cognitive reserve, and Alzheimer's

Baldivia, B., Andrade, V.M., Bueno, O.F.A., 2008. Contribution of education, occupation and cognitively stimulating activities to the formation of cognitive reserve. Dement. Neuropsychol. 2, 173-182. https://doi.org/10.1590/s1980-57642009dn20300003

Bangasser, D.A., Valentino, R.J., 2014. Sex Differences in Stress-Related Psychiatric Disorders: Neurobiological Perspectives. Front Neuroendocr. 2014 35, 303-319. https://doi.org/10.1016/j.yfrne.2014.03.008

Bangasser, D.A., Wicks, B., 2017. Sex-specific mechanisms for responding to stress. J. Neurosci. Res. 95, 75-82. https://doi.org/10.1002/jnr.23812

Bangasser, D.A., Wiersielis, K.R., 2018. Sex differences in stress responses: a critical role for corticotropinreleasing factor. Hormones 17, 5-13. https://doi.org/10.1007/s42000-018-0002-z

Barha, C.K., Davis, J.C., Falck, R.S., Nagamatsu, L.S., Liu-Ambrose, T., 2017. Sex differences in exercise efficacy to improve cognition: A systematic review and meta-analysis of randomized controlled trials in older humans. Front. Neuroendocrinol. https://doi.org/10.1016/j.yfrne.2017.04.002

Barha, C.K., Liu-Ambrose, T., 2018. Exercise and the Aging Brain: Considerations for Sex Differences. Brain Plast. 4, 53-63. https://doi.org/10.3233/BPL-180067

Barulli, D., Stern, Y., 2013. Efficiency, capacity, compensation, maintenance, plasticity: Emerging concepts in cognitive reserve. Trends Cogn. Sci. https://doi.org/10.1016/j.tics.2013.08.012

Beeri, M.S., Rapp, M., Schmeidler, J., Reichenberg, A., Purohit, D.P., Perl, D.P., Grossman, H.T., Prohovnik, I., Haroutunian, V., Silverman, J.M., 2009. Number of children is associated with neuropathology of Alzheimer's disease in women. Neurobiol. Aging 30, 1184-91.

https://doi.org/10.1016/j.neurobiolaging.2007.11.011

Beeson, R., Horton-Deutsch, S., Farran, C., Neundorfer, M., 2000. Loneliness and depression in caregivers of persons with Alzheimer's disease or related disorders. Issues Ment. Health Nurs. 21, 779-806. https://doi.org/10.1080/016128400750044279

Beinhoff, U., Tumani, H., Riepe, M.W., 2009. Applying New Research Criteria for Diagnosis of Early Alzheimer's Disease: Sex and Intelligence Matter. Int. J. Alzheimers. Dis. 2009. https://doi.org/10.4061/2009/638145 Bialystok, E., Craik, F.I.M., Freedman, M., 2007. Bilingualism as a protection against the onset of symptoms of dementia. Neuropsychologia 45, 459-464. https://doi.org/http://dx.doi.org/10.1016/j.neuropsychologia.2006.10.009

Billings, A.G., Moos, R.H., 1981. The role of coping responses and social resources in attenuating the stress of life events. J. Behav. Med. 4, 139-157. https://doi.org/10.1007/BF00844267 
RUNNING HEAD: Sex differences, cognitive reserve, and Alzheimer's

Boots, E.A., Schultz, S.A., Almeida, R.P., Oh, J.M., Koscik, R.L., Dowling, M.N., Gallagher, C.L., Carlsson, C.M., Rowley, H.A., Bendlin, B.B., Asthana, S., Sager, M.A., Hermann, B.P., Johnson, S.C., Okonkwo, O.C., 2015. Occupational complexity and cognitive reserve in a middle-Aged cohort at risk for Alzheimer's Disease. Arch. Clin. Neuropsychol. 30, 634-642. https://doi.org/10.1093/arclin/acv041

Bove, R., Secor, E., Chibnik, L.B., Barnes, L.L., Schneider, J.A., Bennett, D.A., De Jager, P.L., 2014. Age at surgical menopause influences cognitive decline and Alzheimer pathology in older women. Neurology 82, 222229. https://doi.org/10.1212/WNL.0000000000000033

Brayne, C., Gill, C., Huppert, F.A., Barkley, C., Gehlhaar, E., Girling, D.M., O’Connor, D.W., Paykel, E.S., 1995. Incidence of Clinically Diagnosed Subtypes of Dementia in an Elderly Population. Br. J. Psychiatry 167, 255-262. https://doi.org/10.1192/bjp.167.2.255

Bretsky, P.M., Buckwalter, J.G., Seeman, T.E., Miller, C.A., Poirier, J., Schellenberg, G.D., Finch, C.E., Henderson, V.W., 1999a. Evidence for an interaction between apolipoprotein E genotype, gender, and Alzheimer disease. Alzheimer Dis. Assoc. Disord. https://doi.org/10.1097/00002093-199910000-00007

Bretsky, P.M., Buckwalter, J.G., Seeman, T.E., Miller, C.A., Poirier, J., Schellenberg, G.D., Finch, C.E., Henderson, V.W., 1999b. Evidence for an interaction between apolipoprotein E genotype, gender, and Alzheimer disease. Alzheimer Dis. Assoc. Disord. 13, 216-21.

Bright, P., van der Linde, I., 2020. Comparison of methods for estimating premorbid intelligence.

Neuropsychol. Rehabil. 30, 1-14. https://doi.org/10.1080/09602011.2018.1445650

Brodaty, H., Donkin, M., 2009. Family caregivers of people with dementia. Dialogues Clin. Neurosci. 11, 217228. https://doi.org/10.1002/gps.2284

Brown, B.M., Peiffer, J., Rainey-Smith, S.R., 2019. Exploring the relationship between physical activity, betaamyloid and tau: A narrative review. Ageing Res. Rev. https://doi.org/10.1016/j.arr.2019.01.003

Brown, B.M., Rainey-Smith, S.R., Dore, V., Peiffer, J.J., Burnham, S.C., Laws, S.M., Taddei, K., Ames, D., Masters, C.L., Rowe, C.C., Martins, R.N., Villemagne, V.L., 2018. Self-Reported Physical Activity is Associated with Tau Burden Measured by Positron Emission Tomography. J. Alzheimer's Dis. 63, 1299-1305. https://doi.org/10.3233/JAD-170998

Buckley, R.F., Waller, M., Masters, C.L., Dobson, A., 2019. To What Extent Does Age at Death Account for Sex Differences in Rates of Mortality From Alzheimer Disease? Am. J. Epidemiol. 188, 1213-1223. https://doi.org/10.1093/aje/kwz048 
RUNNING HEAD: Sex differences, cognitive reserve, and Alzheimer's

Bupp, M.R.G., Potluri, T., Fink, A.L., Klein, S.L., 2018. The confluence of sex hormones and aging on immunity. Front. Immunol. 9. https://doi.org/10.3389/fimmu.2018.01269

Cabeza, R., Albert, M., Belleville, S., Craik, F.I.M., Duarte, A., Grady, C.L., Lindenberger, U., Nyberg, L., Park, D.C., Reuter-Lorenz, P.A., Rugg, M.D., Steffener, J., Rajah, M.N., 2018. Maintenance, reserve and compensation: the cognitive neuroscience of healthy ageing. Nat. Rev. Neurosci. https://doi.org/10.1038/s41583-018-0068-2

Calvo, N., García, A.M., Manoiloff, L., Ibáñez, A., 2016. Bilingualism and cognitive reserve: A critical overview and a plea for methodological innovations. Front. Aging Neurosci. https://doi.org/10.3389/fnagi.2015.00249

Cannon-Albright, L.A., Foster, N.L., Schliep, K., Farnham, J.M., Teerlink, C.C., Kaddas, H., Tschanz, J., Corcoran, C., Kauwe, J.S.K., 2019. Relative risk for Alzheimer disease based on complete family history. Neurology 92, e1745-e1753. https://doi.org/10.1212/WNL.0000000000007231

Chêne, G., Beiser, A., Au, R., Preis, S.R., Wolf, P.A., Dufouil, C., Seshadri, S., 2015. Gender and incidence of dementia in the Framingham Heart Study from mid-adult life. Alzheimer's Dement. 11, 310-320. https://doi.org/10.1016/j.jalz.2013.10.005

Chertkow, H., Whitehead, V., Phillips, N., Wolfson, C., Atherton, J., Bergman, H., 2010. Multilingualism (but not always bilingualism) delays the onset of Alzheimer disease: Evidence from a bilingual community. Alzheimer Dis. Assoc. Disord. 24, 118-125. https://doi.org/10.1097/WAD.0b013e3181ca1221

Cho, N.H., Shaw, J.E., Karuranga, S., Huang, Y., da Rocha Fernandes, J.D., Ohlrogge, A.W., Malanda, B., 2018. IDF Diabetes Atlas: Global estimates of diabetes prevalence for 2017 and projections for 2045. Diabetes Res. Clin. Pract. 138, 271-281. https://doi.org/10.1016/j.diabres.2018.02.023

Cohen, S., Janicki-deverts, D., Chen, E., Matthews, K.A., 2010. Childhood socioeconomic status and adult health 1186, 37-55. https://doi.org/10.1111/j.1749-6632.2009.05334.x

Colcombe, S., Kramer, A.F., 2003. Fitness Effects on the Cognitive Function of Older Adults. Psychol. Sci. 14, 125-130. https://doi.org/10.1111/1467-9280.t01-1-01430

Colucci, M., Cammarata, S., Assini, A., Croce, R., Clerici, F., Novello, C., Mazzella, L., Dagnino, N., Mariani, C., Tanganelli, P., 2006. The number of pregnancies is a risk factor for Alzheimer's disease. Eur. J. Neurol. 13, 1374-1377. https://doi.org/10.1111/j.1468-1331.2006.01520. 
RUNNING HEAD: Sex differences, cognitive reserve, and Alzheimer's

Corder, E.H., Ghebremedhin, E., Taylor, M.G., Thal, D.R., Ohm, T.G., Braak, H., 2004. The biphasic relationship between regional brain senile plaque and neurofibrillary tangle distributions: Modification by age, sex, and APOE polymorphism. Ann. N. Y. Acad. Sci. 1019, 24-28. https://doi.org/10.1196/annals.1297.005

Corder, E.H., Saunders, A.M., Strittmatter, W.J., Schmechel, D.E., Gaskell, P.C., Small, G.W., Roses, A.D., Haines, J.L., Pericak-Vance, M.A., 1993. Gene dose of apolipoprotein E type 4 allele and the risk of Alzheimer's disease in late onset families. Science (80-. ). 261, 921-923. https://doi.org/10.1126/science.8346443

Corrada, M.M., Brookmeyer, R., Berlau, D., Paganini-Hill, A., Kawas, C.H., 2008. Prevalence of dementia after age 90: Results from the 90+ study. Neurology 71, 337-343.

https://doi.org/10.1212/01.wnl.0000310773.65918.cd

Damoiseaux, J.S., Seeley, W.W., Zhou, J., Shirer, W.R., Coppola, G., Karydas, A., Rosen, H.J., Miller, B.L., Kramer, J.H., Greicius, M.D., Initia, A.D.N., 2012. Gender Modulates the APOE epsilon 4 Effect in Healthy Older Adults: Convergent Evidence from Functional Brain Connectivity and Spinal Fluid Tau Levels. J. Neurosci. 32, 8254-8262. https://doi.org/10.1523/JNEUROSCI.0305-12.2012

Darin-Mattsson, A., Fors, S., Kåreholt, I., 2017. Different indicators of socioeconomic status and their relative importance as determinants of health in old age. Int. J. Equity Health 16, 173. https://doi.org/10.1186/s12939-017-0670-3

Dartigues, J.F., Gagnon, M., Letenneur, L., Barberger-Gateau, P., Commenges, D., Evaldre, M., Salamon, R., 1992. Principal lifetime occupation and cognitive impairment in a french elderly cohort (PAQUID). Am. J. Epidemiol. 135, 981-988. https://doi.org/10.1093/oxfordjournals.aje.a116410

Dekhtyar, S., Wang, H.X., Fratiglioni, L., Herlitz, A., 2016. Childhood school performance, education and occupational complexity: A life-course study of dementia in the Kungsholmen Project. Int. J. Epidemiol. 45, 1207-1215. https://doi.org/10.1093/ije/dyw008

Duffin, E., 2019. • Americans with a college degree 1940-2018, by gender [WWW Document]. Statista. URL https://www.statista.com/statistics/184272/educational-attainment-of-college-diploma-or-higher-bygender/ (accessed 11.5.19).

Dykstra, P.A., Gierveld, J.D.J., 2014. Gender and Marital-History Differences in Emotional and Social Loneliness among Dutch Older Adults *. https://doi.org/10.1353/cja.2004.0018

Einstein, G., 1999. To each her own: sexual dimorphisms in Alzheimer's disease. Neurobiol. Aging 20, 439-40. 
RUNNING HEAD: Sex differences, cognitive reserve, and Alzheimer's

Engelhart, M.J., Geerlings, M.I., Ruitenberg, A., Swieten, J.C. van, Hofman, A., Witteman, J.C.M., Breteler, M.M.B., 2002. Dietary intake of antioxidants and risk of Alzheimer disease. J. Am. Med. Assoc. 287, 32233229. https://doi.org/10.1001/jama.287.24.3261

Erickson, K.I., Voss, M.W., Prakash, R.S., Basak, C., Szabo, A., Chaddock, L., Kim, J.S., Heo, S., Alves, H., White, S.M., Wojcicki, T.R., Mailey, E., Vieira, V.J., Martin, S.A., Pence, B.D., Woods, J.A., McAuley, E., Kramer, A.F., 2011. Exercise training increases size of hippocampus and improves memory. Proc. Natl. Acad. Sci. U. S. A. 108, 3017-22. https://doi.org/10.1073/pnas.1015950108

Evans, G.W., Kim, P., 2010. Multiple risk exposure as a potential explanatory mechanism for the socioeconomic status-health gradient. Ann. N. Y. Acad. Sci. https://doi.org/10.1111/j.17496632.2009.05336.x

Evans, I.E.M., Llewellyn, D.J., Matthews, F.E., Woods, R.T., Brayne, C., Clare, L., Clarra, L., Windle, G., Burholt, V., Philips, J., McCracken, C., Bennett, K., 2018. Social isolation, cognitive reserve, and cognition in healthy older people. PLoS One 13, 1-14. https://doi.org/10.1371/journal.pone.0201008

Farrer, L.A., Cupples, L.A., Haines, J.L., Hyman, B., Kukull, W.A., Mayeux, R., Myers, R.H., Pericak-Vance, M.A., Risch, N., van Duijn, C.M., 1997. Effects of Age, Sex, and Ethnicity on the Association Between Apolipoprotein E Genotype and Alzheimer Disease: A Meta-analysis. JAMA 278, 1349-1356. https://doi.org/10.1001/jama.1997.03550160069041

Finkel, D., Andel, R., Gatz, M., Pedersen, N.L., 2009. The Role of Occupational Complexity in Trajectories of Cognitive Aging Before and After Retirement. Psychol. Aging 24, 563-573.

https://doi.org/10.1037/a0015511

Folkman, S., Lazarus, R.S., 1980. An Analysis of Coping in a Middle-Aged Community Sample Author ( s ): Susan Folkman and Richard S . Lazarus Source : Journal of Health and Social Behavior, Vol . 21 , No . 3 ( Sep ., 1980 ), pp . 219-239 Published by : American Sociological Association S. J. Health Soc. Behav. 21, $219-239$.

Fox, M., Berzuini, C., Knapp, L.A., 2013a. Cumulative estrogen exposure, number of menstrual cycles, and Alzheimer's risk in a cohort of British women. Psychoneuroendocrinology 38, 2973-2982. https://doi.org/10.1016/j.psyneuen.2013.08.005

Fox, M., Berzuini, C., Knapp, L.A., 2013b. Maternal Breastfeeding History and Alzheimer's Disease Risk. J. Alzheimer's Dis. 37, 809-821. https://doi.org/10.3233/JAD-130152

Fratiglioni, L., Ahlbom, A., Viitanen, M., Winblad, B., 1993. Risk Factors for Late-Onset Alzheimer's Disease : A Population-Based, Case-Control Study. Ann. Neurol. 33, 258-266. 
RUNNING HEAD: Sex differences, cognitive reserve, and Alzheimer's

Fratiglioni, L., Grut, M., Forsell, Y., Viitanen, M., Grafstrom, M., Holmen, K., Ericsson, K., Backman, L., Ahlbom, A., Winblad, B., 1991. Prevalence of Alzheimers-Disease and other dementias in an elderly urbanpopulation - relationship with age, sex, and education. Neurology 41, 1886-1892.

https://doi.org/10.1212/WNL.41.12.1886

Fratiglioni, L., Viitanen, M., Von Strauss, E., Tontodonati, V., Herlitz, A., Winblad, B., 1997. Very old women at highest risk of dementia and Alzheimer's disease: Incidence data from the Kungsholmen Project, Stockholm. Neurology 48, 132-138. https://doi.org/10.1212/WNL.48.1.132

Fratiglioni, L., Wang, H., Ericsson, K., Maytan, M., Winblad, B., 2000. Influence of social network on occurrence of dementia: a community-based longitudinal study. Lancet 355, 1315-1319.

Gilsanz, P., Lee, C., Corrada, M.M., Kawas, C.H., Quesenberry, C.P., Whitmer, R.A., 2019. Reproductive period and risk of dementia in a diverse cohort of health care members. Neurology 92, e2005-e2014. https://doi.org/10.1212/WNL.0000000000007326

Gómez-Tortosa, E., Barquero, M.S., Barón, M., Sainz, M.J., Manzano, S., Payno, M., Ros, R., Almaraz, C., Gómez-Garré, P., Jiménez-Escrig, A., 2007. Variability of age at onset in siblings with familial Alzheimer disease. Arch. Neurol. 64, 1743-1748. https://doi.org/10.1001/archneur.64.12.1743

Green, R.C., Cupples, L.A., Go, R., Benke, K.S., Edeki, T., Griffith, P.A., Williams, M., Hipps, Y., Graff-Radford, N., Bachman, D., Farrer, L.A., 2002. Risk of dementia among white and African American relatives of patients with Alzheimer disease. J. Am. Med. Assoc. 287, 329-336. https://doi.org/10.1001/jama.287.3.329

Guiney, H., Lucas, S.J., Cotter, J.D., Machado, L., 2015. Evidence cerebral blood-flow regulation mediates exercise-cognition links in healthy young adults. Neuropsychology 29, 1-9. https://doi.org/10.1037/neu0000124

Guiney, H., Machado, L., 2013. Benefits of regular aerobic exercise for executive functioning in healthy populations. Psychon. Bull. Rev. https://doi.org/10.3758/s13423-012-0345-4

Hamilton, S., Fagot, B.I., 1988. Chronic Stress and Coping Styles: A Comparison of Male and Female Undergraduates. J. Pers. Soc. Psychol. 55, 819-823. https://doi.org/10.1037/0022-3514.55.5.819 
Harold, D., Abraham, R., Hollingworth, P., Sims, R., Gerrish, A., Hamshere, M.L., Pahwa, J.S., Moskvina, V., Dowzell, K., Williams, A., Jones, N., Thomas, C., Stretton, A., Morgan, A.R., Lovestone, S., Powell, J., Proitsi, P., Lupton, M.K., Brayne, C., Rubinsztein, D.C., Gill, M., Lawlor, B., Lynch, A., Morgan, K., Brown, K.S., Passmore, P.A., Craig, D., McGuinness, B., Todd, S., Holmes, C., Mann, D., Smith, A.D., Love, S., Kehoe, P.G., Hardy, J., Mead, S., Fox, N., Rossor, M., Collinge, J., Maier, W., Jessen, F., Schürmann, B., Heun, R., Van Den Bussche, H., Heuser, I., Kornhuber, J., Wiltfang, J., Dichgans, M., Frölich, L., Hampel, H., Hüll, M., Rujescu, D., Goate, A.M., Kauwe, J.S.K., Cruchaga, C., Nowotny, P., Morris, J.C., Mayo, K., Sleegers, K., Bettens, K., Engelborghs, S., De Deyn, P.P., Livingston, G., Bass, N.J., Gurling, H., McQuillin, A., Gwilliam, R., Deloukas, P., Al-Chalabi, A., Shaw, C.E., Tsolaki, M., Singleton, A.B., Guerreiro, R., Mühleisen, T.W., Nöthen, M.M., Moebus, S., Jöckel, K.H., Klopp, N., Wichmann, H.E., Carrasquillo, M.M., Pankratz, V.S., Younkin, S.G., O’Donovan, M., Owen, M.J., Williams, J., 2009. Genome-wide association study identifies variants at CLU and PICALM associated with Alzheimer's disease. Nat. Genet. 41, 1088-1093. https://doi.org/10.1038/ng.440

Hasselgren, C., Ekbrand, H., Fassberg, M.M., Zettergren, A., Zetterberg, H., Blennow, K., Skoog, I., Hallerod, B., 2019. APOE epsilon 4 and the long arm of social inequity: estimated effects of socio-economic status and sex on the timing of dementia onset. AGEING Soc. 39, 1951-1975.

https://doi.org/10.1017/S0144686X18000351

Helmer, C., Damon, D., Letenneur, L., Fabrigoule, C., Barberger-Gateau, P., Lafont, S., Fuhrer, R., Antonucci, T., Commenges, D., Orgogozo, J.M., Dartigues, J.F., 1999. Marital status and risk of Alzheimer's disease: A French population-based cohort study. Am. Acad. Neurol. 53, 1953-1953.

Helmer, C., Letenneur, L., Rouch, I., Richard-Harston, S., Barberger-Gateau, P., Fabrigoule, C., Orgogozo, J.M., Dartigues, J.F., 2001. Occupation during life and risk of dementia in French elderly community residents. J. Neurol. Neurosurg. Psychiatry 71, 303-309. https://doi.org/10.1136/jnnp.71.3.303

Herlitz, A., Rehnman, J., 2008. Sex differences in episodic memory. Curr. Dir. Psychol. Sci. 17, 52-56. https://doi.org/10.1111/j.1467-8721.2008.00547.x

Hillman, C.H., Motl, R.W., Pontifex, M.B., Posthuma, D., Stubbe, J.H., Boomsma, D.I., De Geus, E.J.C., 2006. Physical activity and cognitive function in a cross-section of younger and older community-dwelling individuals. Heal. Psychol. 25, 678-687. https://doi.org/10.1037/0278-6133.25.6.678 
Hohman, T.J., Dumitrescu, L., Barnes, L.L., Thambisetty, M., Beecham, G., Kunkle, B., Gifford, K.A., Bush, W.S., Chibnik, L.B., Mukherjee, S., De Jager, P.L., Kukull, W., Crane, P.K., Resnick, S.M., Keene, C.D., Montine, T.J., Schellenberg, G.D., Haines, J.L., Zetterberg, H., Blennow, K., Larson, E.B., Johnson, S.C., Albert, M., Bennett, D.A., Schneider, J.A., Jefferson, A.L., 2018. Sex-Specific Association of Apolipoprotein E With Cerebrospinal Fluid Levels of Tau. JAMA Neurol. 75, 989-998.

https://doi.org/10.1001/jamaneurol.2018.0821

Holwerda, T.J., Deeg, D.J.H., Beekman, A.T.F., Van Tilburg, T.G., Stek, M.L., Jonker, C., Schoevers, R.A., 2014.

Feelings of loneliness, but not social isolation, predict dementia onset: Results from the Amsterdam Study of the Elderly (AMSTEL). J. Neurol. Neurosurg. Psychiatry 85, 135-142. https://doi.org/10.1136/jnnp2012-302755

Huang, A.R., Strombotne, K.L., Horner, E.M., Lapham, S.J., 2018. Adolescent Cognitive Aptitudes and Later-inLife Alzheimer Disease and Related Disorders. JAMA Netw. open 1, e181726. https://doi.org/10.1001/jamanetworkopen.2018.1726

Irvine, K., Laws, K.R., Gale, T.M., Kondel, T.K., 2012. Greater cognitive deterioration in women than men with Alzheimer's disease: A meta analysis. J. Clin. Exp. Neuropsychol. 34, 989-998. https://doi.org/10.1080/13803395.2012.712676

Jack, C.R., Wiste, H.J., Weigand, S.D., Knopman, D.S., Vemuri, P., Mielke, M.M., Lowe, V., Senjem, M.L., Gunter, J.L., Machulda, M.M., Gregg, B.E., Pankratz, V.S., Rocca, W.A., Petersen, R.C., 2015. Age, sex, and APOE $\in 4$ effects on memory, brain structure, and $\beta$-Amyloid across the adult life Span. JAMA Neurol. 72, 511-519. https://doi.org/10.1001/jamaneurol.2014.4821

Jang, H., Bae, J. Bin, Dardiotis, E., Scarmeas, N., Sachdev, P.S., Lipnicki, D.M., Han, J.W., Kim, T.H., Kwak, K.P., Kim, B.J., Kim, S.G., Kim, J.L., Moon, S.W., Park, J.H., Ryu, S.H., Youn, J.C., Lee, D.Y., Lee, D.W., Lee, S.B., Lee, J.J., Jhoo, J.H., Yannakoulia, M., Kosmidis, M.H., Hadjigeorgiou, G.M., Sakka, P., Kim, K.W., 2018. Differential effects of completed and incomplete pregnancies on the risk of Alzheimer disease. Neurology 91, e643-e651. https://doi.org/10.1212/WNL.0000000000006000

Jayadev, S., Steinbart, E.J., Chi, Y.Y., Kukull, W.A., Schellenberg, G.D., Bird, T.D., 2008. Conjugal Alzheimer disease: Risk in children when both parents have Alzheimer disease. Arch. Neurol. 65, 373-378. https://doi.org/10.1001/archneurol.2007.61 
RUNNING HEAD: Sex differences, cognitive reserve, and Alzheimer's

Kalyani, R.R., Lazo, M., Ouyang, P., Turkbey, E., Chevalier, K., Brancati, F., Becker, D., Vaidya, D., 2014. Sex differences in diabetes and risk of incident coronary artery disease in healthy young and middle-Aged adults. Diabetes Care 37, 830-838. https://doi.org/10.2337/dc13-1755

Kaplan, M.S., Newsom, J.T., McFarland, B.H., Lu, L., 2001. Demographic and psychosocial correlates of physical activity in late life. Am. J. Prev. Med. 21, 306-312. https://doi.org/10.1016/S0749-3797(01)00364-6

Karp, A., Kåreholt, I., Qiu, C., Bellander, T., Winblad, B., Fratiglioni, L., 2004. Relation of Education and Occupation-based Socioeconomic Status to Incident Alzheimer's Disease. Am. J. Epidemiol. 159, 175-183. https://doi.org/10.1093/aje/kwh018

Kautzky-Willer, A., Harreiter, J., 2017. Sex and gender differences in therapy of type 2 diabetes. Diabetes Res. Clin. Pract. 131, 230-241. https://doi.org/10.1016/j.diabres.2017.07.012

Kawas, C., Resnick, S., Morrison, A., Brookmeyer, R., Corrada, M., Zonderman, A., Bacal, C., Donnell Lingle, D., Metter, E., 1997. A prospective study of estrogen replacement therapy and the risk of developing Alzheimer's disease: The Baltimore Longitudinal Study of Aging. Neurology 48, 1517-1521. https://doi.org/10.1212/WNL.48.6.1517

Kessler, R.C., 2003. Epidemiology of women and depression. J. Affect. Disord. 74, 5-13. https://doi.org/https://doi.org/10.1016/S0165-0327(02)00426-3

Kessler, R.C., Demler, O., Frank, R.G., Olfson, M., Pincus, H.A., Walters, E.E., Wang, P., Wells, K.B., Zaslavsky, A.M., 2005. Prevalence and treatment of mental disorders, 1990 to 2003. N. Engl. J. Med. 352, 25152523. https://doi.org/10.1056/NEJMsa043266

Kessler, R.C., McGonagle, K.A., Swartz, M., Blazer, D.G., Nelson, C.B., 1993. Sex and depression in the National Comorbidity Survey I: Lifetime prevalence, chronicity and recurrence. J. Affect. Disord. 29, 85-96. https://doi.org/10.1016/0165-0327(93)90026-G

Koran, M.E.I., Wagener, M., Hohman, T.J., Initiativ, A.N., 2017. Sex differences in the association between AD biomarkers and cognitive decline. Brain Imaging Behav. 11, 205-213. https://doi.org/10.1007/s11682016-9523-8

Launer, L.J., Andersen, K., Dewey, M.E., Letenneur, L., Ott, A., Amaducci, L.A., Brayne, C., Copeland, J.R.M., Dartigues, J.F., Kragh-Sorensen, P., Lobo, A., Martinez-Lage, J.M., Stijnen, T., Hofman, A., 1999. Rates and risk factors for dementia and Alzheimer's disease: Results from EURODEM pooled analyses. Neurology 52, 78-84. https://doi.org/10.1212/wnl.52.1.78 
RUNNING HEAD: Sex differences, cognitive reserve, and Alzheimer's

Laws, K.R., Irvine, K., Gale, T.M., 2018. Sex differences in Alzheimer's disease. Curr. Opin. Psychiatry 31, 133139. https://doi.org/10.1097/YCO.0000000000000401

Lee, K.A., Kryger, M.H., 2008. Women and sleep. J. Women's Heal. 17, 1189-1190.

https://doi.org/10.1089/jwh.2007.0574

Lee, Y., Kim, W.S., Paik, N.J., 2017. Gender differences in physical activity and health-related behaviors among stroke survivors: Data from the 5th Korea National Health and nutrition examination survey. Top. Stroke Rehabil. 24, 381-387. https://doi.org/10.1080/10749357.2017.1304877

Lee, Y.S., 2005. Gender differences in physical activity and walking among older adults. J. Women Aging 17, 55-70. https://doi.org/10.1300/J074v17n01_05

Letellier, N., Gutierrez, L.-A., Carriere, I., Gabelle, A., Dartigues, J.-F., Dufouil, C., Helmer, C., Cadot, E., Berr, C., 2018. Sex-specific association between neighborhood characteristics and dementia: The Three-City cohort. ALZHEIMERS Dement. 14, 473-482. https://doi.org/10.1016/j.jalz.2017.09.015

Letenneur, L., Gilleron, V., Commenges, D., Helmer, C., Orgogozo, J.M., Dartigues, J.F., 1999. Are sex and educational level independent predictors of dementia and Alzheimer's disease? Incidence data from the PAQUID project. J. Neurol. Neurosurg. Psychiatry 66, 177-183. https://doi.org/10.1136/jnnp.66.2.177 Letenneur, L., Launer, L.J., Andersen, K., Dewey, M.E., Ott, A., Copeland, J.R.M., Dartigues, J.F., KraghSorensen, P., Baldereschi, M., Brayne, C., Lobo, A., Martinez-Lage, J.M., Stijnen, T., Hofman, A., 2000. Education and the risk for Alzheimer's disease: Sex makes a difference. EURODEM pooled analyses. Am. J. Epidemiol. 151, 1064-1071. https://doi.org/10.1093/oxfordjournals.aje.a010149

Li, F.-D., He, F., Chen, T.-R., Xiao, Y.-Y., Lin, S.-T., Shen, W., Wang, X.-Y., Zhai, Y.-J., Shang, X.-P., Lin, J.-F., 2016. Reproductive History and Risk of Cognitive Impairment in Elderly Women: A Cross-Sectional Study in Eastern China. J. Alzheimer's Dis. 49, 139-147. https://doi.org/10.3233/JAD-150444

Liming Alspaugh, M.E., Stephens, M.A.P., Townsend, A.L., Greene, R., Zarit, S.H., 1999. Longitudinal patterns of risk for depression in dementia caregivers: Objective and subjective primary stress as predictors. Psychol. Aging 14, 34-43. https://doi.org/10.1037/0882-7974.14.1.34

Lo, R.Y., Jagust, W.J., Initative, for the A.D.N., 2013. Effect of Cognitive Reserve Markers on Alzheimer Pathological Progression Raymond. Alzheimer Dis. Assoc. Disord. 27, 1-14. https://doi.org/10.1038/jid.2014.371

Lovejoy, J.C., Sainsbury, A., 2009. Sex differences in obesity and the regulation of energy homeostasis: Etiology and pathophysiology. Obes. Rev. 10, 154-167. https://doi.org/10.1111/j.1467-789X.2008.00529.x 
RUNNING HEAD: Sex differences, cognitive reserve, and Alzheimer's

Maddrey, A.M., Cullum, C.M., Weiner, M.F., Filley, C.M., 1996. Premorbid intelligence estimation and level of dementia in Alzheimer's disease. J. Int. Neuropsychol. Soc. 2, 551-555.

https://doi.org/10.1017/s1355617700001727

Mallampalli, M.P., Carter, C.L., 2014. Exploring sex and gender differences in sleep health: A society for women's health research report. J. Women's Heal. 23, 553-562. https://doi.org/10.1089/jwh.2014.4816

Malpetti, M., Ballarini, T., Presotto, L., Garibotto, V., Tettamanti, M., Perani, D., 2017. Gender differences in healthy aging and Alzheimer's Dementia: A18F-FDG-PET study of brain and cognitive reserve. Hum. Brain Mapp. 38, 4212-4227. https://doi.org/10.1002/hbm.23659

Matthews, K.A., Gallo, L.C., 2010. Psychological Perspectives on Pathways Linking Socioeconomic Status and Physical Health. https://doi.org/10.1146/annurev.psych.031809.130711

McCarrey, A.C., An, Y., Kitner-Triolo, M.H., Ferrucci, L., Resnick, S.M., 2016. Sex Differences in Cognitive Trajectories in Clinically Normal Older Adults. Psychol. Aging 31, 166-175.

https://doi.org/10.1037/pag0000070

McGeer, P.L., Rogers, J., McGeer, E.G., 2016. Inflammation, Antiinflammatory Agents, and Alzheimer's Disease: The Last 22 Years. J. Alzheimers. Dis. 54, 853-857. https://doi.org/10.3233/JAD-160488

McLay, R.N., Maki, P.M., Lyketsos, C.G., 2003. Nulliparity and late menopause are associated with decreased cognitive decline. J. Neuropsychiatry Clin. Neurosci. 15, 161-167. https://doi.org/10.1176/jnp.15.2.161

Mclean, C.P., Asnaani, A., Litz, B.T., Hofmann, S.G., 2011. Gender differences in anxiety disorders: Prevalence, course of illness, comorbidity and burden of illness. J. Psychiatr. Res. 45, 1027-1035.

https://doi.org/10.1016/j.jpsychires.2011.03.006

Meng, X., D'Arcy, C., 2012. Education and dementia in the context of the cognitive reserve hypothesis: A systematic review with meta-analyses and qualitative analyses. PLoS One 7. https://doi.org/10.1371/journal.pone.0038268

Merchant, C., Tang, M.-X., Albert, S., Manly, J., Stern, Y., Mayeux, R., 1999. The influence of smoking on the risk of Alzheimer's disease [4] (multiple letters). Neurology 52, 1408-1412. https://doi.org/10.1212/WNL.54.3.777-a

Merlo, S., Spampinato, S.F., Sortino, M.A., 2017. Estrogen and Alzheimer's disease: Still an attractive topic despite disappointment from early clinical results. Eur. J. Pharmacol. 817, 51-58. https://doi.org/10.1016/j.ejphar.2017.05.059 
RUNNING HEAD: Sex differences, cognitive reserve, and Alzheimer's

Miech, R.A., Breitner, J.C.S., Zandi, P.P., Khachaturian, A.S., Anthony, J.C., Mayer, L., 2002. Incidence of AD may decline in the early 90s for men, later for women: The Cache County study. Neurology 58, 209-218. https://doi.org/10.1212/WNL.58.2.209

Mielke, M., Vemuri, P., Rocca, W., 2014. Clinical epidemiology of Alzheimer's disease : assessing sex and gender differences. Clin. Epidemiol. 37-48.

Miller, V.T., LaRosa, J., Barnabei, V., Kessler, C., Levin, G., Smith-Roth, A., Griffin, M., Stoy, D.B., Bush, T., Zacur, H., Foster, D., Anderson, J., McKenzie, A., Miller, S., Wood, P.D., Stefanick, M.L., Marcus, R., Akana, A., Heinrichs, W.L., Kirchner, C., O’Hanlan, K., Ruyle, M., Sheehan, M., Judd, H.L., Greendale, G., Bayalos, R., Lozano, K., Kawakami, K., Barrett-Connor, E., Langer, R., Kritz-Silverstein, D., Carrion-Petersen, M. Lou, Cavero, C., Schrott, H.G., Johnson, S.R., Feddersen, D.A., Krutzfeldt, D.L., Benda, J.A., Pauerstein, C., Trabal, J., Schenken, R., Stern, M.P., Rodriguez-Sifuentes, M., Easton, C., Wells, H., Espeland, M., Howard, G., Byington, R., Legault, C., Shumaker, S., Hogan, P., Hire, D., Wasilauskas, C., James, M., Lane, K., Terrell, T., Reece, S., Pierce, J., Snow, M., Anthony, S., Mebane-Sims, I.L., Einhorn, P., Hunsberger, S., Waclawiw, M., Lippel, K., Lucas, D., Verter, J., Jackson, S., Kelaghan, J., Perlman, J., Wolf, P., McGowan, J., Gordon, S., Heyse, S., Fradkin, J., Sherman, S., Page, L., Sorenson, A., Hulka, B., Brody, B., Burkman, R., Heaney, R., Krauss, R., Roberts, H., Wittes, J., Riggs, L., Moss, R., Albers, J., Marcovina, S., Fineberg, S.E., Tracy, R.P., Merino, M., Scully, R., Livolsi, V., Kessler, G., 1995. Effects of Estrogen or Estrogen/ Progestin Regimens on Heart Disease Risk Factors in Postmenopausal Women: The Postmenopausal Estrogen/Progestin Interventions (PEPI) Trial. JAMA 273, 199-208. https://doi.org/10.1001/jama.1995.03520270033028 Moceri, V.M., Kukull, W.A., Emanual, I., Belle, G. Van, Starr, J.R., Schellenberg, G.D., Mccormick, W.C., Bowen, J.D., Larson, E.B., Moceri, V.M., Kukull, W.A., Emanual, I., Belle, G. Van, Starr, J.R., Schellenberg, G.D., Mccormick, W.C., Bowe, J.D., Teri, L., Larson, E.B., 2000. Using Census Data and Birth Certificates to Reconstruct the Early-Life Socioeconomic Environment and the Relation to the Development of Alzheimer ' s Disease Linked references are available on JSTOR for this article : Using Census Data and Birth Certifica. Montine, T.J., Cholerton, B.A., Corrada, M.M., Edland, S.D., Flanagan, M.E., Hemmy, L.S., Kawas, C.H., White, L.R., 2019. Concepts for brain aging: Resistance, resilience, reserve, and compensation. Alzheimer's Res. Ther. 11, 10-12. https://doi.org/10.1186/s13195-019-0479-y

Morris, M.C., Evans, D.A., Bienias, J.L., Tangney, C.C., Bennett, D.A., Aggarwal, N., Wilson, R.S., Scherr, P.A., 2002. Dietary intake of antioxidant nutrients and the risk of incident Alzheimer disease in a biracial community study. J. Am. Med. Assoc. 287, 3230-3237. https://doi.org/10.1001/jama.287.24.3230 
RUNNING HEAD: Sex differences, cognitive reserve, and Alzheimer's

Mosca, L., Barrett-Connor, E., Kass Wenger, N., 2011. Sex/gender differences in cardiovascular disease prevention: What a difference a decade makes. Circulation 124, 2145-2154.

https://doi.org/10.1161/CIRCULATIONAHA.110.968792

Mosconi, L., Rahman, A., Diaz, I., Wu, X., Scheyer, O., Hristov, H.W., Vallabhajosula, S., Isaacson, R.S., de Leon, M.J., Brinton, R.D., 2018. Increased Alzheimer's risk during the menopause transition: A 3-year longitudinal brain imaging study. PLoS One 13, e0207885. https://doi.org/10.1371/journal.pone.0207885

Nebel, R.A., Aggarwal, N.T., Barnes, L.L., Gallagher, A., Goldstein, J.M., Kantarci, K., Mallampalli, M.P., Mormino, E.C., Scott, L., Yu, W.H., Maki, P.M., 2018. Understanding the impact of sex and gender in Alzheimer's disease: A call to action. Alzheimer's Dement. 14, 1171-1183.

https://doi.org/http://dx.doi.org/10.1016/j.jalz.2018.04.008

Neu, S.C., Pa, J., Kukull, W., Beekly, D., Kuzma, A., Gangadharan, P., Wang, L.-S., Romero, K., Arneric, S., Redolfi, A., Orlandi, D., Frisoni, G., Au, R., Devine, S., Auerbach, S., Espinosa, A., Boada, M., Ruiz, A., Johnson, S.C., Koscik, R., Wang, J.-J., Hsu, W.-C., Chen, Y.-L., Toga, A.W., 2017. Apolipoprotein E Genotype and Sex Risk Factors for Alzheimer's Disease. JAMA Neurol. 74, 1178-1189.

https://doi.org/10.1001/jamaneurol.2017.2188.Apolipoprotein

Nicoll, G., Almey, A., Gervais, N., 2020. Disentangling the effects of aging and ovarian hormone loss on sleep: implications for health and disease, in: Neuroscience of Aging.

Njølstad, I., Arnesen, E., Lund-Larsen, P.G., 1996. Smoking, Serum Lipids, Blood Pressure, and Sex Differences in Myocardial Infarction. Circulation 93, 450-456. https://doi.org/10.1161/01.CIR.93.3.450

Norton, M.C., Smith, K.R., Østbye, T., Tschanz, J.T., Corcoran, C., Schwartz, S., Piercy, K.W., Rabins, P. V., Steffens, D.C., Skoog, I., Breitner, J.C.S., Welsh-Bohmer, K.A., 2010. Greater risk of sementia when spouse has dementia? the cache county study: [See editorial comments by Dr. Peter P. Vitaliano, pp 976-978]: BRIEF REPORTS. J. Am. Geriatr. Soc. 58, 895-900. https://doi.org/10.1111/j.1532-5415.2010.02806.x Norton, Smith, K.R., Østbye, T., Tschanz, J.T., Corcoran, C., Schwartz, S., Piercy, K.W., Rabins, P. V, Steffens, D.C., Skoog, I., Breitner, J.C.S., Welsh-Bohmer, K.A., Cache County Investigators, 2010. Greater risk of dementia when spouse has dementia? The Cache County study. J. Am. Geriatr. Soc. 58, 895-900. https://doi.org/10.1111/j.1532-5415.2010.02806.x 
RUNNING HEAD: Sex differences, cognitive reserve, and Alzheimer's

Okonkwo, O.C., Schultz, S.A., Oh, J.M., Larson, J., Edwards, D., Cook, D., Koscik, R., Gallagher, C.L., Dowling, N.M., Carlsson, C.M., Bendlin, B.B., LaRue, A., Rowley, H.A., Christian, B.T., Asthana, S., Hermann, B.P., Johnson, S.C., Sager, M.A., 2014. Physical activity attenuates age-related biomarker alterations in preclinical AD. Neurology 83, 1753-1760. https://doi.org/10.1212/WNL.0000000000000964

Oliveira, F.F., Chen, E.S., Smith, M.C., Bertolucci, P.H.F., 2016. Predictors of Cognitive and Functional Decline in Patients With Alzheimer Disease Dementia From Brazil. Alzheimer Dis. Assoc. Disord. 30, 243-250.

Osone, A., Arai, R., Hakamada, R., Shimoda, K., 2015. Impact of cognitive reserve on the progression of mild cognitive impairment to Alzheimer's disease in Japan. Geriatr. Gerontol. Int. 15, 428-434. https://doi.org/10.1111/ggi.12292

Ott, Alewijn, Breteler, M.M.B., Van Harskamp, F., Stijnen, T., Hofman, A., 1998. Incidence and risk of dementia: The Rotterdam Study. Am. J. Epidemiol. 147, 574-580.

https://doi.org/10.1093/oxfordjournals.aje.a009489

Ott, A., Slooter, A.J.C., Hofman, A., Van Harskamp, F., Witteman, J.C.M., Van Broeckhoven, C., Van Duijn, C.M., Breteler, M.M.B., 1998. Smoking and risk of dementia and Alzheimer's disease in a population-based cohort study: The Rotterdam Study. Lancet 351, 1840-1843. https://doi.org/10.1016/S01406736(97)07541-7

Pankratz, V.S., Roberts, R.O., Mielke, M.M., Knopman, D.S., Jack, C.R., Geda, Y.E., Rocca, W.A., Petersen, R.C., 2015. Predicting the risk of mild cognitive impairment in the Mayo Clinic Study of Aging. Neurology 84, 1433-1442. https://doi.org/10.1212/WNL.0000000000001437

Parker, G., Brotchie, H., 2010. Gender differences in depression. Int. Rev. Psychiatry 22, 429-436. https://doi.org/10.3109/09540261.2010.492391

Perani, D., Abutalebi, J., 2015. Bilingualism, dementia, cognitive and neural reserve. Curr. Opin. Neurol. 28, 618-625. https://doi.org/10.1097/WCO.0000000000000267

Perneczky, R., Diehl-Schmid, J., Foerstl, H., Drzezga, A., Kurz, A., 2007a. Male gender is associated with greater cerebral hypometabolism in frontotemporal dementia: evidence for sex-related cognitive reserve. Int. J. Geriatr. Psychiatry 22, 1135-1140. https://doi.org/10.1002/gps.1803

Perneczky, R., Drzezga, A., Diehl-Schmid, J., Li, Y., Kurz, A., 2007b. Gender differences in brain reserve - An F18-FDG PET study in Alzheimer's disease. J. Neurol. 254, 1395-1400. https://doi.org/10.1007/s00415007-0558-z 
RUNNING HEAD: Sex differences, cognitive reserve, and Alzheimer's

Pfefferbaum, A., Rohlfing, T., Rosenbloom, M.J., Chu, W., Colrain, I.M., Sullivan, E. V., 2013. Variation in longitudinal trajectories of regional brain volumes of healthy men and women (ages 10 to 85years) measured with atlas-based parcellation of MRI. Neuroimage 65, 176-193.

https://doi.org/10.1016/j.neuroimage.2012.10.008

Podcasy, J.L., Epperson, C.N., 2016. Considering sex and gender in Alzheimer disease and other dementias.

Dialogues Clin. Neurosci. 18, 437-446. https://doi.org/10.1016/j.jcin.2015.10.034

Pradier, C., Sakarovitch, C., Duff, F. Le, Layese, R., Metelkina, A., Anthony, S., Tifratene, K., Robert, P., 2014.

The Mini Mental State Examination at the Time of Alzheimer's Disease and Related Disorders Diagnosis, According to Age , Education, Gender and Place of Residence : A Cross-Sectional Study among the French National Alzheimer Database 9. https://doi.org/10.1371/journal.pone.0103630

Prince, M., Ali, G.C., Guerchet, M., Prina, A.M., Albanese, E., Wu, Y.T., 2016. Recent global trends in the prevalence and incidence of dementia, and survival with dementia. Alzheimer's Res. Ther. 8. https://doi.org/10.1186/s13195-016-0188-8

Qiu, C., Karp, A., Von Strauss, E., Winblad, B., Fratiglioni, L., Bellander, T., 2003. Lifetime principal occupation and risk of Alzheimer's disease in the Kungsholmen Project. Am. J. Ind. Med. 43, 204-211. https://doi.org/10.1002/ajim.10159

Reckelhoff, J., 2001. Gender Differences in the Regulation of Blood Pressure. Hypertension 37, 1199-1208. https://doi.org/10.1161/01.HYP.37.5.1199

Richardson, T.J., Lee, S.J., Berg-Weger, M., Grossberg, G.T., 2013. Caregiver health: Health of caregivers of Alzheimer's and other dementia patients topical collection on geriatric disorders. Curr. Psychiatry Rep. 15. https://doi.org/10.1007/s11920-013-0367-2

Roberts, R.O., Geda, Y.E., Knopman, D.S., Cha, R.H., Pankratz, V.S., Boeve, B.F., Tangalos, E.G., Ivnik, R.J., Rocca, W.A., Petersen, R.C., 2012. The incidence of MCl differs by subtype and is higher in men: The Mayo Clinic study of aging. Neurology 78, 342-351. https://doi.org/10.1212/WNL.0b013e3182452862

Rocca, W.A., Bower, J.H., Maraganore, D.M., Ahlskog, J.E., Grossardt, B.R., de Andrade, M., Melton, L.J., 2007. Increased risk of cognitive impairment or dementia in women who underwent oophorectomy before menopause. Neurology 69, 1074-1083. https://doi.org/10.1212/01.wnl.0000276984.19542.e6

Rose-Rego, S.K., Strauss, M.E., Smyth, K.A., 1998. Differences in the perceived well-being of wives and husbands caring for persons with Alzheimer's disease. Gerontologist 38, 224-230. https://doi.org/10.1093/geront/38.2.224 
RUNNING HEAD: Sex differences, cognitive reserve, and Alzheimer's

Ruitenberg, A., Ott, A., Van Swieten, J.C., Hofman, A., Breteler, M.M.B., 2001. Incidence of dementia: Does gender make a difference? Neurobiol. Aging 22, 575-580. https://doi.org/10.1016/S01974580(01)00231-7

Russo, J., Vitaliano, P.P., Brewer, D.D., Katon, W., Becker, J., 1995. Psychiatric Disorders in Spouse Caregivers of Care Recipients With Alzheimer's Disease and Matched Controls: A Diathesis-Stress Model of Psychopathology. J. Abnorm. Psychol. 104, 197-204. https://doi.org/10.1037/0021-843X.104.1.197

Santabarbara, J., Gracia-Rebled, A.C., Lopez-Anton, R., Tomas, C., Lobo, E., Marcos, G., Lobo, A., 2019. The effect of occupation type on risk of Alzheimer's disease in men and women. Maturitas 126, 61-68. https://doi.org/10.1016/j.maturitas.2019.05.008

Scarmeas, N., Levy, G., Tang, M.-X., Manly, J., Stern, Y., 2001. Influence of leisure activity on the incidence of Alzheimer's Disease. Neurology 57, 2236-2242. https://doi.org/10.1016/S0020-1383(96)00079-4

Schmidt, R., Kienbacher, E., Benke, T., Dal-Bianco, P., Delazer, M., Ladurner, G., Jellinger, K., Marksteiner, J., Ransmayr, G., Schmidt, H., Stögmann, E., Friedrich, J., Wehringer, C., 2008. [Sex differences in Alzheimer's disease]. Neuropsychiatr. 22, 1-15.

Schulz, R., Williamson, G.M., Morycz, R.K., Biegel, D.E., 1992. Costs and benefits of providing care to Alzheimer's patients., in: Helping and Being Helped: Naturalistic Studies., The Claremont Symposium on Applied Psychology. Sage Publications, Inc, Thousand Oaks, CA, US, pp. 153-181.

Shao, H., Breitner, J.C.S., Whitmer, R.A., Wang, J., Hayden, K., Wengreen, H., Corcoran, C., Tschanz, J.A., Norton, M., Munger, R., Welsh-Bohmer, K., Zandi, P.P., 2012. Hormone therapy and Alzheimer disease dementia: New findings from the Cache County Study. Neurology 79, 1846-1852. https://doi.org/10.1212/WNL.0b013e318271f823

Shye, D., Mullooly, J.P., Freeborn, D.K., Pope, C.R., 1995. Gender differences in the relationship between social network support and mortality: a longitudinal study of an elderly cohort. Soc. Sci. Med. 41, 935-47. https://doi.org/10.1016/0277-9536(94)00404-h

Sinforiani, E., Citterio, A., Zucchella, C., Bono, G., Corbetta, S., Merlo, P., Mauri, M., 2010. Impact of Gender Differences on the Outcome of Alzheimer's Disease. Dement. Geriatr. Cogn. Disord. 30, 147-154. https://doi.org/10.1159/000318842

Smart, E.L., Gow, A.J., Deary, I.J., 2014. Occupational complexity and lifetime cognitive abilities. Neurology 83, 2285-2291. https://doi.org/10.1212/WNL.0000000000001075 
RUNNING HEAD: Sex differences, cognitive reserve, and Alzheimer's

Sohn, D., Shpanskaya, K., Lucas, J.E., Petrella, J.R., Saykin, A.J., Tanzi, R.E., Nagiza, F.S., Doraiswamy, P.M., 2018. Sex Differences in Cognitive Decline in Subjects with High Likelihood of Mild Cognitive Impairment due to Alzheimer' s disease 1-9. https://doi.org/10.1038/s41598-018-25377-w

Sörman, D.E., Hansson, P., Pritschke, I., Ljungberg, J.K., 2019. Complexity of primary lifetime occupation and cognitive processing. Front. Psychol. 10, 1-12. https://doi.org/10.3389/fpsyg.2019.01861

Statistics Canada, 2015. Women and Education [WWW Document]. Women Canada A Gender-based Stat. Rep. URL https://www150.statcan.gc.ca/n1/pub/89-503-x/2010001/article/11542-eng.htm (accessed 11.5.19).

Stern, Y., 2012. Cognitive reserve in ageing and Alzheimer's disease. Lancet Neurol. https://doi.org/10.1016/S1474-4422(12)70191-6

Stern, Y., 2009. Cognitive reserve. Neuropsychologia. https://doi.org/10.1016/j.neuropsychologia.2009.03.004

Stern, Y., 2006. Cognitive Reserve and Alzheimer Disease 20, 112-117.

Stern, Y., 2002. What is cognitive reserve? Theory and research application of the reserve concept. J. Int. Neuropsychol. Soc. 8, 448-460. https://doi.org/10.1017/S1355617702813248

Stone, A.A., Neale, J.M., 1984. New measure of daily coping: Development and preliminary results. J. Pers. Soc. Psychol. 46, 892-906. https://doi.org/10.1037/0022-3514.46.4.892

Subramaniapillai, S., Rajah, M.N., Pasvanis, S., Titone, D., 2018. Bilingual experience and executive control over the adult lifespan: The role of biological sex. Biling. Lang. Cogn. 1-19. https://doi.org/10.1017/S1366728918000317

Sundermann, Biegon, A., Rubin, L.H., Lipton, R.B., Mowrey, W., Landau, S., Maki, P.M., 2016a. Better verbal memory in women than men in $\mathrm{MCl}$ despite similar levels of hippocampal atrophy. Neurology 86, 13681376. https://doi.org/10.1212/WNL.0000000000002570

Sundermann, Maki, P., Biegon, A., Lipton, R.B., Mielke, M.M., Machulda, M., Bondi, M.W., 2019. Sex-specific norms for verbal memory tests may improve diagnostic accuracy of amnestic $\mathrm{MCl}$. Neurology 10.1212/WNL.0000000000008467. https://doi.org/10.1212/WNL.0000000000008467

Sundermann, Maki, P.M., Rubin, L.H., Lipton, R.B., Landau, S., Biegon, A., Neuroimaging, A.D., 2016b. Female advantage in verbal memory Evidence of sex-specific cognitive reserve. Neurology 87, 1916-1924. https://doi.org/10.1212/WNL.0000000000003288

Sundermann, Tran, M., Maki, P.M., Bondi, M.W., 2018. Sex differences in the association between apolipoprotein E \&4 allele and Alzheimer's disease markers. Alzheimer's Dement. Diagnosis, Assess. Dis. Monit. 10, 438-447. https://doi.org/10.1016/j.dadm.2018.06.004 
RUNNING HEAD: Sex differences, cognitive reserve, and Alzheimer's

Sundström, A., Westerlund, O., Kotyrlo, E., 2016. Marital status and risk of dementia : a nationwide population-based prospective study from Sweden 1-7. https://doi.org/10.1136/bmjopen-2015-008565

Tang, M.X., Jacobs, D., Stern, Y., Marder, K., Schofieid, P., Garland, B., Andrews, H., Mayeux, R., 1996. Effect of oestrogen during menopause on risk and age at onset of Alzheimer's disease. Lancet 348, 429-432. https://doi.org/10.1016/S0140-6736(96)03356-9

Tannenbaum, C., Ellis, R.P., Eyssel, F., Zou, J., Schiebinger, L., 2019. Sex and gender analysis improves science and engineering. Nature 575, 137-146. https://doi.org/10.1038/s41586-019-1657-6

Treiber, K.A., Carlson, M.C., Corcoran, C., Norton, M.C., Breitner, J.C.S., Piercy, K.W., DeBerand, M.S., Stein, D., Foley, B., Welsh-Bohmer, K.A., Frye, A., Lyketsos, C.G., Tschanz, J.T., 2011. Cognitive Stimulation and Cognitive and Functional Decline in Alzheimer's Disease: The Cache County Dementia Progression Study. Journals Gerontol. Ser. B Psychol. Sci. Soc. Sci. 66, 416-425.

Van Uffelen, J.G.Z., Chinapaw, M.J.M., Van Mechelen, W., Hopman-Rock, M., 2008. Walking or vitamin B for cognition in older adults with mild cognitive impairment? A randomised controlled trial. Br. J. Sports Med. 42, 344-351. https://doi.org/10.1136/bjsm.2007.044735

Wang, H.-X., Macdonald, S.W.S., Dekhtyar, S., Fratiglioni, L., 2017. Association of lifelong exposure to cognitive reserve-enhancing factors with dementia risk: A community-based cohort study. https://doi.org/10.1371/journal.pmed.1002251

Weissman, M.M., Klerman, G.L., 1977. Sex Differences and the Epidemiology of Depression. Arch. Gen. Psychiatry 34, 98-111. https://doi.org/10.1001/archpsyc.1977.01770130100011

Whitmer, R.A., Quesenberry, C.P., Zhou, J., Yaffe, K., 2011. Timing of hormone therapy and dementia: The critical window theory revisited. Ann. Neurol. 69, 163-169. https://doi.org/10.1002/ana.22239

Wight, R.G., Aneshensel, C.S., Seeman, T.E., 2002. Educational attainment, continued learning experience, and cognitive function among older men. J. Aging Health 14, 211-236.

https://doi.org/10.1177/089826430201400203

Yanes, L.L., Reckelhoff, J.F., 2011. Postmenopausal hypertension. Am. J. Hypertens. 24, 740-749. https://doi.org/10.1038/ajh.2011.71

Zhang, B., Wing, Y.K., 2006. Sex differences in insomnia: A meta-analysis. Sleep 29, 85-93. https://doi.org/10.1093/sleep/29.1.85 


\section{Tables and Figures}

Table 1. Sex differences in risk factors for Alzheimer's disease

\begin{tabular}{|c|c|c|c|}
\hline Risk Factor & Sex Prevalence Findings & Age & References \\
\hline Age & $\begin{array}{l}\text { 1. } \mathbf{W}>\mathbf{M} \text { : Even after controlling for longevity the } \\
\text { rate of } A D \text { is higher in women. } \\
\text { 2. The risk for } A D \text { doubles approximately every } 5 \\
\text { years after the age of } 65 \text { years. }\end{array}$ & OA (>65yrs) & $\begin{array}{l}\text { 1. Alzheimer's Association, } 2019 . \\
\text { 2. Buckley et al., 2019; Prince et al., } \\
2016 .\end{array}$ \\
\hline Biological Sex & $\begin{array}{l}\text { 1. } \mathbf{W}>\mathbf{M} \text { : Females are at greater risk of } \\
\text { developing } A D \text { than men. }\end{array}$ & OA (>75yrs) & $\begin{array}{l}\text { 1. Chêne et al., 2015; Bailly et al., } \\
\text { 2019; Einstein, } 1999 .\end{array}$ \\
\hline $\begin{array}{l}\text { Family History } \\
\text { of } A D\end{array}$ & $\begin{array}{l}\text { 1. In offspring with } 2 \mathrm{AD} \text { parents } 20 \% \text { risk of } A D \\
\text { at } 70 y \text { rs and } 60 \% \text { risk of } A D \text { at } 80 y r s . \\
\text { 2. } \mathbf{W}>\mathbf{M} \text { : Women with first degree relative with } \\
A D \text { have greater } A D \text { risk. } \\
\text { 3. } \mathbf{M}>\mathbf{W} \text { : When more distant relatives included } \\
\text { men have greater } A D \text { risk. }\end{array}$ & OA (>65yrs) & $\begin{array}{l}\text { 1. Jayadev et al., } 2008 \\
\text { 2. Green et al. } 2002 \\
\text { 3. Cannon-Albright et al. } 2019\end{array}$ \\
\hline $\begin{array}{l}\text { Genetic Risk: } \\
\text { APOE4 }\end{array}$ & $\begin{array}{l}\text { 1. APOE4 allele is the strongest genetic predictor } \\
\text { for late onset AD. } \\
\text { 2. } \mathbf{W}>\mathbf{M} \text { : Pro- and retro- spective studies show } \\
\text { higher AD in female APOE4 carriers. } \\
\text { 3. } \mathbf{W}>\mathbf{M} \text { : Female APOE4 carriers have greater } \\
\text { accumulation of neurofibrillary tangles (tau). } \\
\text { 4. } \mathbf{W}>\mathbf{M} \text { : Female APOE4 carriers have greater } \\
\text { accumulation of senile plaques (amyloid). }\end{array}$ & $\begin{array}{l}\text { 1. OA (>65yrs) } \\
\text { 2. OA ( 75yrs) } \\
\text { 3. OA (>70yrs) } \\
\text { 4. MA+OA, } \\
\text { greatest } \\
\text { plaque } \\
\text { accumulation } \\
\text { 55-65yrs. }\end{array}$ & $\begin{array}{l}\text { 1. Harold et al., } 2009 \\
\text { 2. Altman et al., } 2014 \\
\text { 3. Damoiseaux et al., 2012; Hohman } \\
\text { et al., } 2018 \\
\text { 4. Corder et al., } 2004 .\end{array}$ \\
\hline Inflammation & $\begin{array}{l}\text { 1. Elevated inflammation increases the risk of } A D \text {, } \\
\text { and extended use of anti-inflammatories } \\
\text { reduces AD risk. } \\
\text { 2. } \mathbf{W}>\mathbf{M} \text { : Higher prevalence of autoimmune } \\
\text { disorders in women (i.e. multiple sclerosis) } \\
\text { suggesting elevated immune activation. } \\
\text { 3. W>M: Type II Diabetes: earlier onset in males } \\
\text { BUT W>M once diagnosed - greater } \\
\text { cardiovascular decline in women. }\end{array}$ & $\begin{array}{l}\text { 1. } \mathrm{MA}+\mathrm{OA} \\
\text { 2. } \mathrm{YA}(\sim 20 \mathrm{yrs}) \\
\text { 3. } \mathrm{MA}+\mathrm{OA}\end{array}$ & $\begin{array}{l}\text { 1. Reviewed in McGeer et al., } 2016 \\
\text { 2. Bupp et al., } 2018 \\
\text { 3. Cho et al., 2018; Kalyani et al., } \\
\text { 2014; Kautzky-Willer et al., } 2017\end{array}$ \\
\hline
\end{tabular}

Abbreviations: $A D=A$ lzheimer's disease; $A P O E 4=a p o l i p o p r o t e i n ~ a l l e l e ~ 4 ; ~ M>W=$ men more affected than women; $M A=$ middle adulthood; $O A=$ older adulthood; $W>M=$ women more affected than men; $W=M$ no difference; $Y A=y o u n g$ adulthood.

Note: Articles in the table are not an exhaustive review, but instead represent a selection of research and reviews over the past 20 years. 
Table 2. Women's reproductive risk factors for Alzheimer's disease

\begin{tabular}{|c|c|c|c|}
\hline Female hormone contribution to AD & Participants & Comments & Reference(s) \\
\hline \multicolumn{4}{|l|}{ Parturition and Alzheimer's Risk/Pathology } \\
\hline $\begin{array}{l}\text { - } 1-2 \text { pregnancies }=1.8 \mathrm{x} \text { increase risk for } \mathrm{AD} \\
\text { - } 3 \text { pregnancies }=3.2 \mathrm{x} \text { increased risk for } \mathrm{AD} \\
\text { - }>3 \text { pregnancies }=\mathrm{AD} \text { 4yrs earlier }\end{array}$ & $\begin{array}{l}\text { Total } n=405 \text { (women) } \\
A D n=204, \text { avg } 75 y r s \\
\text { Controls } n=201, \text { avg } \\
74 y r s\end{array}$ & $\begin{array}{l}\text { - Statistics did not covary for } \\
\text { group differences. } \\
\text { - } \text { HT use reduced risk for AD }\end{array}$ & $\begin{array}{l}\text { Colucci et al., } \\
2006\end{array}$ \\
\hline $\begin{array}{l}\text { - } \quad \geq 5 \text { completed pregnancies increase AD 1.7x (Li et al.) } \\
\text { - } \quad \geq 2 \text { completed pregnancies worse MMSE (Jang et al.) } \\
\text { - } \geq 1 \text { incomplete pregnancy reduced AD risk by half (Li et } \\
\text { al.), better performance on MMSE (Jang et al.) }\end{array}$ & $\begin{array}{l}\text { Total } n=2737 \text { (women, } \\
\text { avg } 73 y r s-L i \text { et al.) } \\
\text { Total } n=3499 \text { (women, } \\
\text { avg } 72 y \text { rs - Jang et al.) }\end{array}$ & $\begin{array}{l}\text { - Oral contraceptive and IUD } \\
\text { use protect against cognitive } \\
\text { impairment (Li et al., 2016) }\end{array}$ & $\begin{array}{l}\text { Jang et al., } \\
2018 \\
\text { Li et al., } 2016\end{array}$ \\
\hline $\begin{array}{l}\text { - Women: \# offspring associated with higher total AD } \\
\text { pathology and plaques (entorhinal + amygdala) } \\
\text { - Men: \# offspring unrelated to AD pathology }\end{array}$ & $\begin{array}{l}\text { Total } n=73 \\
\text { Women } n=42 \\
\text { Men } n=31\end{array}$ & $\begin{array}{l}\text { Total AD pathology via plaque } \\
\text { and tangle count in multiple } \\
\text { ROls }\end{array}$ & $\begin{array}{l}\text { Beeri et al., } \\
2009\end{array}$ \\
\hline $\begin{array}{l}\text { - \# pregnancies and younger age at menopause associated } \\
\text { with decline on MMSE over } 12.8 \mathrm{yrs}\end{array}$ & $\begin{array}{l}\text { Total } n=316 \text { (women, avg } \\
64 y r s) \\
\quad \text { Menopausal at } 3^{\text {rd }} \text { visit }\end{array}$ & $\begin{array}{l}\text { - Covary for age, education, oral } \\
\text { contraceptive, and others }\end{array}$ & $\begin{array}{l}\text { McLay et al., } \\
2003\end{array}$ \\
\hline $\begin{array}{l}\text { - } \text { More months breast feeding = reduced } A D \text { risk } \\
\text { - Larger ratio of months breastfeeding to months pregnant } \\
\text { associated with reduced risk of } A D \\
\text { - } \quad \text { First child }<21 \mathrm{yrs} \text { increases risk for } A D\end{array}$ & $\begin{array}{l}\text { Total } n=81 \text { (>75yrs) } \\
\quad \text { Total AD } n=40\end{array}$ & $\begin{array}{l}\text { - Breastfeeding counteracts } \\
\text { multiparity effect on risk of } A D\end{array}$ & $\begin{array}{l}\text { Fox et al., } \\
2013 b\end{array}$ \\
\hline \multicolumn{4}{|l|}{ Spontaneous/Surgical Menopause and Alzheimer's Risk/Pathology } \\
\hline $\begin{array}{l}\text { - Dementia } 2 x \text { higher if surgical menopause } \leq 45 y r s \\
\text { - Risk higher if younger at surgery }(<38 y r s) \\
\text { - } \text { ET post-surgery eliminates increase in dementia risk }\end{array}$ & $\begin{array}{l}\text { Total surgical meno. } n=1 \\
472 ; A D n=150 \\
\text { Total control } n=1489, A D \\
n=98\end{array}$ & $\begin{array}{l}\text { Mixed uni- and bi- lateral } \\
\text { ovary removal and } \\
\text { hysterectomy }\end{array}$ & $\begin{array}{l}\text { Rocca et al., } \\
2007\end{array}$ \\
\hline $\begin{array}{l}\text { - Surgical menopause: faster decline in episodic and } \\
\text { semantic memory, elevated AD pathology } \\
\text { - HT use within 5yrs of surgery protective } \\
\text { - Trend toward positive associations: } \\
\text { a) surgical menopause + AD } \\
\text { b) spontaneous menopause age + memory }\end{array}$ & $\begin{array}{l}\text { Total } n=1884 \text { (women, avg } \\
\text { 78yrs at study end) } \\
\text { Followed for } 18 y r s \\
\quad \sim 1 / 3 \text { surgical menopause }\end{array}$ & $\begin{array}{l}\text { - } \mathrm{HT}=\text { systemic or local } \\
\text { estrogen and/or progestin }\end{array}$ & $\begin{array}{l}\text { Bove et al., } \\
2014\end{array}$ \\
\hline $\begin{array}{l}\text { - Verbal memory decline more in post vs. men } \\
\text { - Hippocampal and frontal metabolism decline more in peri } \\
\text { and post vs. pre and men } \\
\text { - More } \beta \text {-amyloid accumulation in frontal cortex of peri } \\
\text { and post vs. pre and men }\end{array}$ & $\begin{array}{l}\text { Pre, peri, post menopausal } \\
\text { and men }(47,53,58,52 \mathrm{yrs} \text {, } \\
\text { respectively) } \\
\mathrm{n}=\sim 15 \text { per group } \\
\text { Tested 3yrs apart }\end{array}$ & $\begin{array}{l}\text { - Exclude for surgical } \\
\text { menopause, ET, and cancer } \\
\text { history. } \\
\text { - Controlled for age and APOE4 }\end{array}$ & $\begin{array}{l}\text { Mosconi et } \\
\text { al., } 2018\end{array}$ \\
\hline $\begin{array}{l}\text { - Each month ovarian hormone exposure (menarche- } \\
\text { menopause) reduced risk of AD by } 0.5 \% \\
\text { - Trend for \# menstrual cycles reducing risk for AD }\end{array}$ & $\begin{array}{l}\text { Total } n=89 \text { (women, } 70- \\
\text { 100yrs) } \\
\text { AD } n=38 \\
\text { Control } n=51\end{array}$ & $\begin{array}{l}\text { Menarche/menopause age, } \\
\text { and oral contraceptives not } \\
\text { related to risk for AD }\end{array}$ & $\begin{array}{l}\text { Fox et al., } \\
2013 a\end{array}$ \\
\hline \multicolumn{4}{|l|}{ Estrogen Therapy and Alzheimer's Risk/Pathology } \\
\hline $\begin{array}{l}\text { - Risk of AD lower if with ET post-menopause } \\
\text { - Unrelated to duration of ET or age at menopause }\end{array}$ & $\begin{array}{l}\text { Total } n=514 \text { (women, avg. } \\
78 y r s \text { at study end) } \\
\text { ET for } \geq 1 y r n=231 \\
\text { Control } n=283\end{array}$ & $\begin{array}{l}\text { ET = conjugated equine } \\
\text { estrogens or estradiol } \\
\text { - Mix spontaneous and surgical }\end{array}$ & $\begin{array}{l}\text { Kawas et al., } \\
1997\end{array}$ \\
\hline $\begin{array}{l}\text { - } \quad \text { ET reduced risk of } A D \\
\text { - } A D \text { incidence } 5 y r s: 2.7 \% \text { ET, } 8.4 \% \text { non-ET }\end{array}$ & $\begin{array}{l}\text { Total } n=1124 \text { (women, avg } \\
74 y r s) \\
\text { ET } n=156 \text {, avg 73yrs }\end{array}$ & $\begin{array}{l}\text { - ET primarily conjugated } \\
\text { equine estrogens } \\
\text { - Mix spontaneous and surgical } \\
\text { menopause }\end{array}$ & $\begin{array}{l}\text { Tang et al., } \\
1996\end{array}$ \\
\hline
\end{tabular}

Abbreviations: $A D=A l z h e i m e r ' s$ disease; APOE4=apolipoprotein allele 4; $E T=$ systemic estrogen therapy; HT=hormone therapy of any type; MMSE=Mini-Mental State Exam

Note: Articles in the table are not an exhaustive review, but instead represent a selection of research over the past 25 years. 
Table 3. Sex differences in general health moderators that contribute to risk of Alzheimer's disease

\begin{tabular}{|c|c|c|c|}
\hline $\begin{array}{l}\text { General Health } \\
\text { Factor }\end{array}$ & Sex Prevalence Findings & Age & References \\
\hline $\begin{array}{l}\text { Mental Health: } \\
\text { Depression } \\
\text { Anxiety } \\
\text { Stress }\end{array}$ & $\begin{array}{l}\text { 1. } \mathbf{W}>\mathbf{M} \text { : Depression more common in women. } \\
\text { 2. } \mathbf{W}>\mathbf{M} \text { : Anxiety disorders more common in } \\
\text { women. } \\
\text { 3. } \mathbf{W}>\mathbf{M} \text { : Elevated psychosocial stress in } \\
\text { women contributes to depression/anxiety. }\end{array}$ & $\begin{array}{l}\text { Begins at YA, } \\
\text { persists } \\
\text { through MA } \\
\text { and OA }\end{array}$ & $\begin{array}{l}\text { 1. Reviewed in Kessler et al., } 2005 \\
\text { 2. McLean et al., 2011, reviewed in } \\
\text { Kessler et al., } 2005 \\
\text { 3. Bangasser \& Wiersielis, } 2018\end{array}$ \\
\hline $\begin{array}{l}\text { Cardiovascular } \\
\text { Health: } \\
\text { Blood Pressure }\end{array}$ & $\begin{array}{l}\text { 1. } \mathbf{M}>\mathbf{W} \text { : Higher blood pressure at middle age. } \\
\text { 2. } \mathbf{W}>\mathbf{M} \text { : Higher blood pressure post- } \\
\text { menopause; shift in cardiovascular risk. }\end{array}$ & $M A, O A$ & $\begin{array}{l}\text { 1. Yanes \& Reckelhoff, } 2011 \\
\text { 2. Miller et al., 1995; Reckelhoff, } 2001\end{array}$ \\
\hline Obesity & $\begin{array}{l}\text { 1. } \mathbf{W}>\mathbf{M} \text { : Globally, women more overweight } \\
\text { and obese than men. }\end{array}$ & YA, MA, OA & $\begin{array}{l}\text { 1. Lovejoy et al., 2009; } \\
\text { https://www.worldobesity.org/ }\end{array}$ \\
\hline Smoking & $\begin{array}{l}\text { 1. } \mathbf{M}>\mathbf{W} \text { : Men use more tobacco products. } \\
\text { 2. } \mathbf{W}>\mathbf{M} \text { : Smoking is a stronger risk factor for } \\
\text { coronary heart disease in women. }\end{array}$ & YA, MA, OA & $\begin{array}{l}\text { 1. https://www.drugabuse.gov/public } \\
\frac{\text { ations/research-reports/tobacco- }}{\text { nicotine-e-cigarettes/are-there- }} \\
\text { gender-differences-in-tobacco- } \\
\text { 2. } \frac{\text { smoking }}{\text { Njølstad et al., } 1996}\end{array}$ \\
\hline $\begin{array}{l}\text { Cardiovascular } \\
\text { Disease }\end{array}$ & $\begin{array}{l}\text { Coronary artery disease: } \\
\qquad \mathbf{M}>\mathbf{W} \text { in absence of diabetes } \\
\quad \mathbf{M}=\mathbf{W} \text { in presence of diabetes } \\
\text { Cardiovascular Disease: } \\
\quad \mathbf{W}>\mathbf{M} \text { - lifetime risk after 40yrs } \\
\text { Stroke: } \mathbf{W}>\mathbf{M} \text { - after 20yrs } \\
\text { Heart failure: } \mathbf{M}>\mathbf{W} \text { - after } 20 y r s \\
\text { Coronary Heart Disease: } \mathbf{M}>\mathbf{F} \text { - after 20yrs }\end{array}$ & YA, MA, OA & Kalyani et al., 2014; Mosca et al., 2011 \\
\hline Sleep & $\begin{array}{l}\text { 1. } \mathbf{W}>\mathbf{M} \text { : Insomnia more common in women. } \\
\text { 2. } \mathbf{W}>\mathbf{M} \text { : Poorer self-reported sleep quality. } \\
\text { 3. } \mathbf{W}>\mathbf{M} \text { : More sleep disorders in women } \\
\text { during puberty, pregnancy, menopause. }\end{array}$ & YA, MA, OA & $\begin{array}{l}\text { 1. Zhang et al., } 2006 \\
\text { 2. Mallampalli et al., } 2014 \\
\text { 3. Mallampalli et al., 2014; Lee \& } \\
\text { Kryger, 2008; Nicholl, Almey, \& } \\
\text { Gervais, } 2020\end{array}$ \\
\hline
\end{tabular}

Abbreviations: $\mathrm{M}>\mathrm{W}=$ men more affected than women; $\mathrm{MA}=$ middle adulthood; $\mathrm{OA}=$ older adulthood; $\mathrm{W}>\mathrm{M}=\mathrm{women}$ more affected than men; $\mathrm{W}=\mathrm{M}$ no difference; $Y A=$ young adulthood.

Note: Articles in the table are not an exhaustive review, but instead represent a selection of research over the past 25 years. 


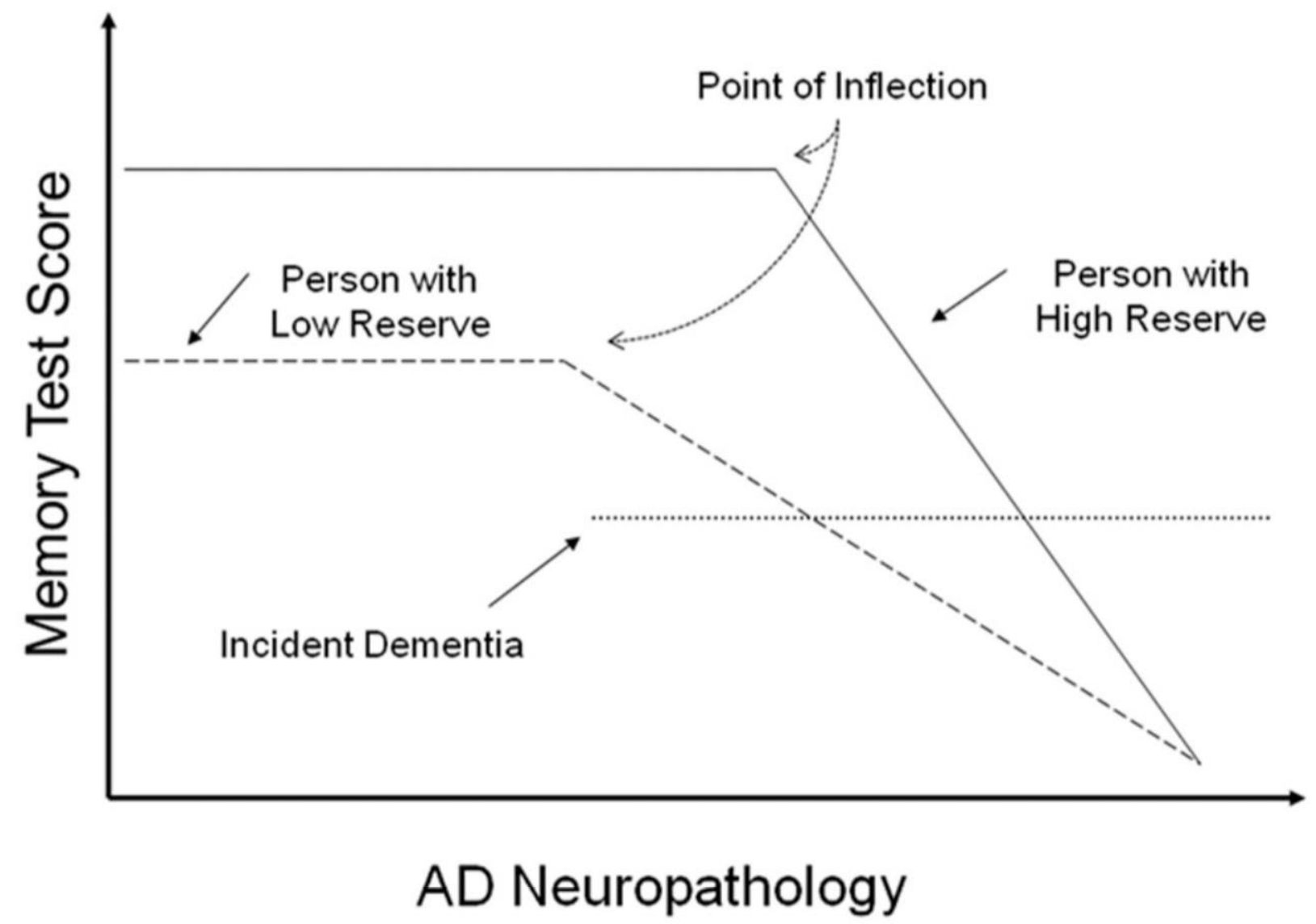

Figure 1. Theoretical depiction of how accumulation of reserve may affect the onset and progression of cognitive decline and diagnosis with mild cognitive impairment/Alzheimer's disease. Resistance is greater in individuals with greater reserve accumulation, reflected in a later point of inflection. Resilience is hypothesized to be lower in individuals who resist cognitive decline for longer, reflected in steeper decline in memory performance after the point of inflection (reproduced with permission from Stern, 2009). 


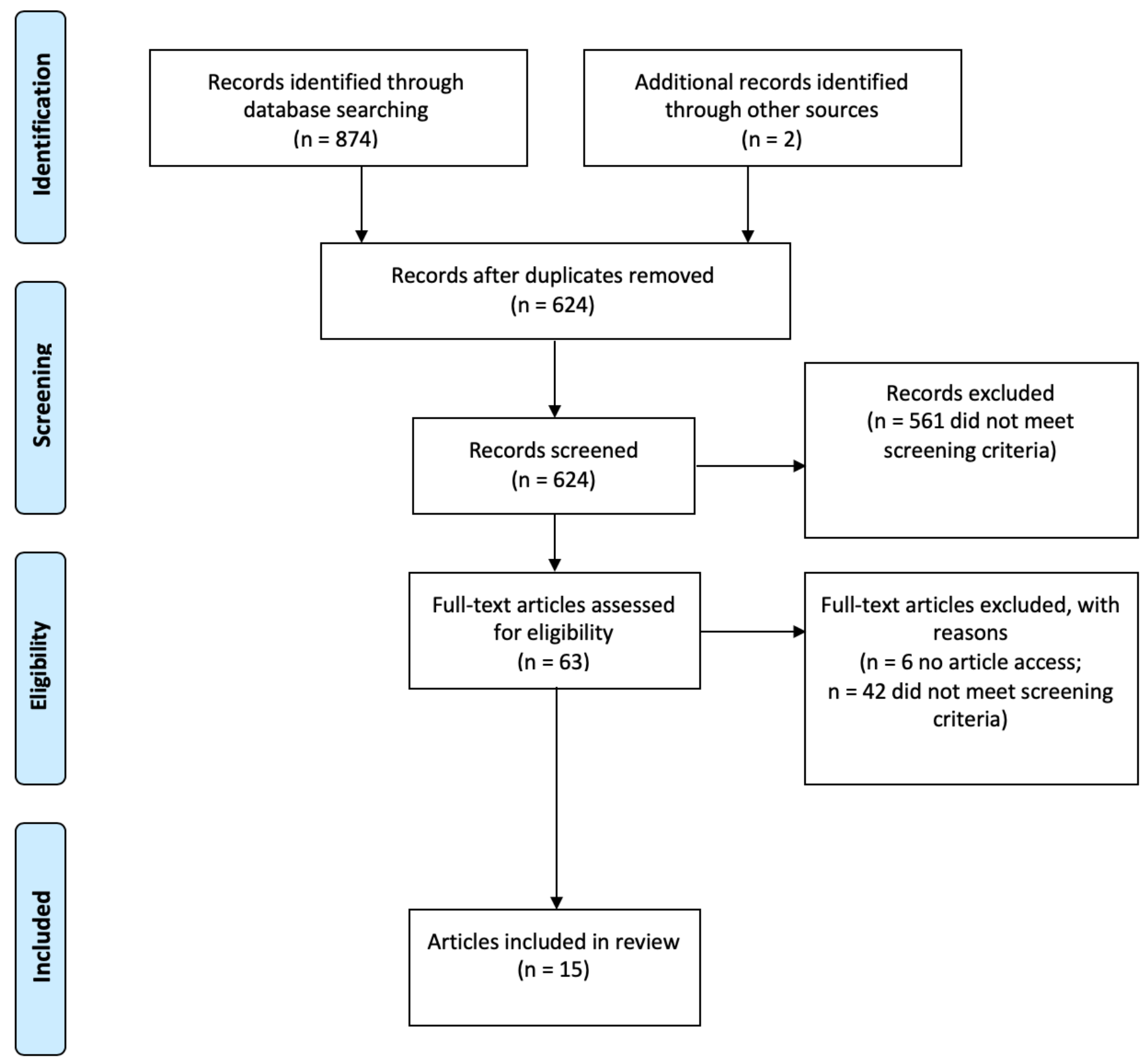

Figure 2. PRISMA flow diagram depicting the selection of papers for this review. 
RUNNING HEAD: Sex differences, cognitive reserve, and Alzheimer's

Table 4. Sex Differences in contributors to cognitive reserve

\begin{tabular}{|c|c|c|c|c|}
\hline Sex Differences in Reserve Contributors & Study Size & Age & Demographics & Reference \\
\hline \multicolumn{5}{|l|}{ Education } \\
\hline $\begin{array}{l}\text { Reserve capacity: } \mathbf{F}=\mathbf{M} \\
\text { - No Sex*Education interaction on AD risk }\end{array}$ & $\begin{array}{l}\text { Total } n=2881 \\
\text { AD } n=140 \text { (women } n \\
=98, \text { men } n=42 \text { ) }\end{array}$ & $>65 y r s$ & $\begin{array}{l}\text { PAQUID Cohort: } \\
\text { random selection } \\
\text { from electoral rolls in } \\
\text { south-west France }\end{array}$ & $\begin{array}{l}\text { Letenneur et } \\
\text { al., } 1999\end{array}$ \\
\hline $\begin{array}{l}\text { Reserve capacity: } \mathbf{F}>\mathbf{M} \\
\text { - Women: low/moderate education increased risk of } \\
\text { - } A D \text { risk compared to high education. } \\
\text { - Men: Education did not affect risk of } A D\end{array}$ & $\begin{array}{l}\text { Total } n=12954 \\
A D n=328(\text { women } n \\
=233, \text { men } n=95)\end{array}$ & $>65 y r s$ & $\begin{array}{l}\text { EURODEM cohort: } \\
\text { selection from } \\
\text { Odense (Denmark), } \\
\text { PAQUID (France), } \\
\text { Rotterdam (Holland), } \\
\text { MRC-ALPHA (United } \\
\text { Kingdom) }\end{array}$ & $\begin{array}{l}\text { Letenneur et } \\
\text { al., } 2000\end{array}$ \\
\hline $\begin{array}{l}\text { Reserve capacity: } \mathbf{M}=\mathbf{F} \\
\text { - Education negatively correlated with } \\
\text { hypometabolism: } \\
\text { - Women: frontal + med. temporal } \\
\text { - Men: lat. temporal, parietal, occipital } \\
\text { - Occupational negatively correlated with } \\
\text { hypometabolism: } \\
\text { - Women: inferior temporal cortex } \\
\text { - Men: precuneus, cingulate, lat. temporal, } \\
\text { parietal }\end{array}$ & $\begin{array}{l}\text { AD } n=282 \text { (women } n \\
=159, \text { men } n=123 \text { ) } \\
\text { Control } n=225 \\
\text { (women } n=110, \text { men } \\
n=115 \text { ) }\end{array}$ & $>60 y r s$ & $\begin{array}{l}\text { ADNI cohort (United } \\
\text { States), NEST-DD } \\
\text { cohort (mixed } \\
\text { European), and } \\
\text { Nuclear Medicine } \\
\text { Database (Milan, } \\
\text { Italy) }\end{array}$ & $\begin{array}{l}\text { Malpetti et } \\
\text { al., } 2017\end{array}$ \\
\hline $\begin{array}{l}\text { Reserve capacity: } \mathbf{M}=\mathbf{F} \\
\text { - Education associated with higher MMSE in both } \\
\text { men and women }\end{array}$ & $\begin{array}{l}\text { Total } n=39451 \\
\text { (women } n=25643 \text {, } \\
\text { men } n=13808 \text { ) }\end{array}$ & $>60 y r s$ & $\begin{array}{l}\text { BNA cohort: } \\
\text { longitudinal database } \\
\text { recruiting from } \\
\text { memory clinics in } \\
\text { France }\end{array}$ & $\begin{array}{l}\text { Pradier et al., } \\
2014\end{array}$ \\
\hline $\begin{array}{l}\text { Reserve capacity: } \mathbf{F}>\mathbf{M} \\
\text { - Education(yrs) negatively correlated with time for } \\
\text { MMSE decline in women but not men (no APOE4) } \\
\text { - Education(yrs) negatively correlated with time for } \\
\text { Clinical Dementia Rating decline in women but not } \\
\text { men (APOE4) }\end{array}$ & $\begin{array}{l}\text { AD } n=214 \text { (women } n \\
=146, \text { men } n=68)\end{array}$ & $>60 y r s$ & $\begin{array}{l}\text { AD patients at } \\
\text { Behavioral Neurology } \\
\text { Section of Hospital } \\
\text { Sao Paulo. Followed } \\
\text { up over } 44 \text { months }\end{array}$ & $\begin{array}{l}\text { Oliveira et al., } \\
2016\end{array}$ \\
\hline $\begin{array}{l}\text { Reserve capacity: } \mathbf{W}=\mathbf{M} \\
\text { - Education (elementary vs. secondary/university) did } \\
\text { not affect risk of AD in women or men } \\
\text { - } A D \text { combined with vascular dementia: } \\
\text { - Women: secondary/university had reduced risk } \\
\text { of dementia compared to elementary } \\
\text { - Men no effect of education on risk of dementia }\end{array}$ & $\begin{array}{l}\text { Total } n=2368 \\
\text { AD } n=116 \text { (women }= \\
98, \text { men }=18 \text { ) } \\
\text { Dementia } n=216 \\
\text { (women }=177, \text { men } \\
=39 \text { ) }\end{array}$ & $>75 y r s$ & $\begin{array}{l}\text { Recruited from } \\
\text { Kungsholmen parish } \\
\text { in Sweden from } \\
1987-88\end{array}$ & $\begin{array}{l}\text { Fratiglioni et } \\
\text { al., } 1991\end{array}$ \\
\hline $\begin{array}{l}\text { Reserve capacity: } \mathbf{W}>\mathbf{M} \\
\text { - Women: } \beta \text {-amyloid predicted worse executive } \\
\text { function at follow-up compared to men } \\
\text { - Sex difference most pronounced among individuals } \\
\text { with low education }\end{array}$ & $\begin{array}{l}\text { Total } n=1098 \\
\text { AD } n=185 \text { (women } n \\
=85, \text { men } n=100)\end{array}$ & $\begin{array}{l}\text { Avg: } \\
74 y r s\end{array}$ & $\begin{array}{l}\text { ADNI cohort: } \\
\text { selected if cognitive } \\
\text { data and CSF for } \beta \text { - } \\
\text { amyloid and Tau }\end{array}$ & $\begin{array}{l}\text { Koran et al., } \\
2017\end{array}$ \\
\hline
\end{tabular}




\begin{tabular}{|c|c|c|c|c|}
\hline $\begin{array}{l}\text { Reserve capacity: } \mathbf{W}>\mathbf{M} \\
\text { - Less education (yrs) increased risk of AD risk in } \\
\text { women but not in men. } \\
\text { - Women: <8yrs education, relative risk AD } 4.55 \\
\text { - Men: <8yrs education, relative risk AD } 1.00\end{array}$ & $\begin{array}{l}\text { Total } n=28768 \\
\text { (women } n=16498 \\
\text { men } n=12270 \text { ) } \\
\text { AD } n=352 \text { (women } n \\
=256, \text { men } n=96 \text { ) }\end{array}$ & $>65 y r s$ & $\begin{array}{l}\text { EURODERM cohort: } \\
\text { those who developed } \\
\text { AD at follow-up (see } \\
\text { above for cohort } \\
\text { details) }\end{array}$ & $\begin{array}{l}\text { Launer et al., } \\
1999\end{array}$ \\
\hline
\end{tabular}

IQ

Reserve capacity: $\mathbf{M}>\mathbf{W}$

- Low IQ women performed worse than men on delayed visuospatial task despite similar CSF tau

- Women: low IQ performed worse high IQ

- Men: IQ did not affect performance

Reserve capacity: $\mathbf{M}=\mathbf{W}$
- Lower high school IQ and academic achievement
increased odds ratio for AD in older adulthood

- Odds identical in men and women

\begin{tabular}{|c|c|c|c|}
\hline $\begin{array}{l}A D n=68 \\
\text { male low IQ }(n=20) \text {, } \\
\text { male high IQ }(n=18) \text {, } \\
\text { female low IQ }(n= \\
15) \\
\text { female high IQ ( } n= \\
15) \text {. }\end{array}$ & $\begin{array}{l}\text { Avg: } \\
\text { 69.5yrs }\end{array}$ & $\begin{array}{l}\text { Dementia clinics at } \\
\text { hospitals in Berlin } \\
\text { and Ulm, Germany } \\
\text { Post-AD IQ: low }>100 \text {, } \\
\text { high }<100\end{array}$ & $\begin{array}{l}\text { Beinhoff et } \\
\text { al., } 2009\end{array}$ \\
\hline $\begin{array}{l}\text { Total women } n=42 \\
749 \\
\text { AD women } n=1416 \\
\text { Total men } n=43014 \\
\text { AD men } n=1238\end{array}$ & $>65 y r s$ & $\begin{array}{l}\text { Project Talent } \\
\text { cohort: } 1960 \text { high } \\
\text { school IQ, data linked } \\
\text { to medicare in } 2016 \\
\text { for AD diagnoses }\end{array}$ & $\begin{array}{l}\text { Huang et al., } \\
2018\end{array}$ \\
\hline
\end{tabular}

\section{Occupational Complexity}

\section{Reserve capacity: $M=W$}

- Women: lower probability AD among farmers than homemakers

- Men: lower probability AD among farmers and white-collar jobs than other occupations

Reserve capacity: $M=W$

- Women: manual work involving goods production associated with greater risk of $A D$

- Men: no association between general or goods productional manual work and risk of $A D$

\section{Reserve capacity: $M=W$}

- Occupation categories didn't modify risk of AD until sex stratified

- Women: being a craftsman/ shopkeeper was AD protective

- Men: being a craftsman/ shopkeeper increased $A D$ risk

\begin{tabular}{|c|c|c|c|}
\hline $\begin{array}{l}\text { Total: women } n= \\
2161 \text {, men } n=1722 \\
\text { AD: women } n=90 \text {, } \\
\text { men }=38\end{array}$ & $>55 y r s$ & $\begin{array}{l}\text { Sample from } 1991 \\
\text { census (Zaragoza, } \\
\text { Spain) } \\
\text { Longitudinal 4-wave } \\
\text { study (1994-2006) }\end{array}$ & $\begin{array}{l}\text { Santabárbara } \\
\text { et al., } 2019\end{array}$ \\
\hline $\begin{array}{l}\text { Total } n=913 \\
\text { AD at 6yr follow-up: } \\
\text { Women } n=166 \\
\text { Men }=n=31\end{array}$ & $>75 y r s$ & $\begin{array}{l}\text { Recruited from } \\
\text { Kungsholmen, } \\
\text { Sweden } \\
\text { Longitudinal: 2-wave } \\
\text { study (1987-1996) }\end{array}$ & $\begin{array}{l}\text { Qiu et al., } \\
2003\end{array}$ \\
\hline $\begin{array}{l}\text { Total } n=2950 \\
\text { baseline } \\
\text { Total AD } n=251 \text { (Sex } \\
\text { differences in AD \# } \\
\text { not specified) } \\
\text { Craftsmen/shopkeep } \\
\text { er } \\
n=499(11.3 \% W ; \\
16.7 \% M)\end{array}$ & $>65 y r s$ & $\begin{array}{l}\text { Recruited from } \\
\text { Gironde/Dordogne, } \\
\text { France } \\
\text { Longitudinal 10-year } \\
\text { follow-up (1988- } \\
\text { 1997) }\end{array}$ & $\begin{array}{l}\text { Helmer et al., } \\
2001\end{array}$ \\
\hline
\end{tabular}

Abbreviations: $A D=A \mid z h e i m e r ' s$ disease; $A P O E 4=a p o l i p o p r o t e i n ~ a l l e l e ~ 4 ; ~ M>W=$ men more affected than women; $M A=m i d d l e$ adulthood; $O A=$ older adulthood; $W>M=$ women more affected than men; $W=M$ no difference; $Y A=y o u n g$ adulthood.

Note: Articles in the table met the search criteria for our narrative review. 